\title{
Lived Experiences of Cancer Patients from Death Anxiety Based on Jaspers Borderline Situations
}

\author{
Ali Imanzadeh ${ }^{1,}$, (D), Fatemeh Sharifi ${ }^{2,}$
}

\begin{abstract}
${ }^{1}$ Associate Professor in Philosophy of Education, Department of Education, Tabriz University, Tabriz, Iran
${ }^{2}$ M.A. Graduated in philosophy of education, Department of Psychology and Education, Malayer University, Hamedan, Iran

* Corresponding author: Ali Imanzadeh, Associate Professor in Philosophy of Education, Department of Education, Tabriz University, Tabriz, Iran. E-mail: aliimanzadeh@tabrizu.ac.ir
\end{abstract}

Received: 30 Nov 2017

Accepted: 05 May 2018

Abstract
Introduction: Introduction Each of the schools of thought, philosophy and religion has different views on
death and its treatment. One of the most common problems of cancer patients challenging with even after
the end of the treatment is the anxiety of death. The purpose of this study is investigating lived experiences
of patients challenging with cancer, who were hospitalized in Baqiyatollah hospital in Tehran.
Methods: This research is qualitative approach and interpretative phenomenological method. The sample
of study was 20 volunteer patients of Cancer department of Baqiatollah hospital, who were selected by the
purposive sampling. Data were collected through in-depth semi-structured interviews. The interviews
continued until saturation of the data. After recording and writing the content of interviews, interviews were
analyzed based on Dickelman, Tanner and Ellen (1989) method.
Results: From the analysis of the patients' lived experiences of cancer, 4 main themes appeared: the concept
of death in patients' attitude, the disease outcomes, the causes of death anxiety and factors reducing death
anxiety and also 23 sub-themes were found.
Conclusions: Based on the findings, it can be concluded that a Comprehensive care plan should be
developed to reduce the death anxiety of life of cancer patients at the borderline position.
Keywords: Lived Experience, Cancer, Death Anxiety (C) 2018 Iranian Nursing Scientific Association (INA) 


\title{
تجربيات زيسته بيماران سرطانى از اضطراب مركى با تكيه بر ديدكاه موقعيتهاى مرزى ياسڤيرس
}

\author{
على ايمانزاده ا.**، (iD)، فاطمه شريفى
}

$$
\begin{aligned}
& \text { ' دانشيار فلسفه تعليم و تربيت، دانشكده روان شناسى و علوم تربيتى، دانشكاه تبريز، تبريز، ايران }
\end{aligned}
$$

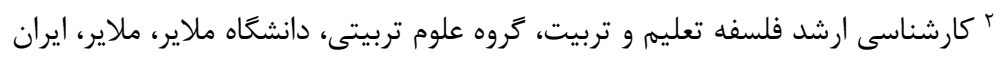

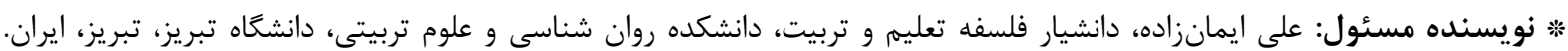
ايميل: aliimanzadeh@tabrizu.ac.ir

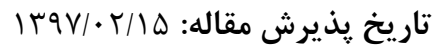

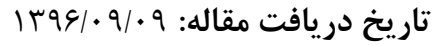

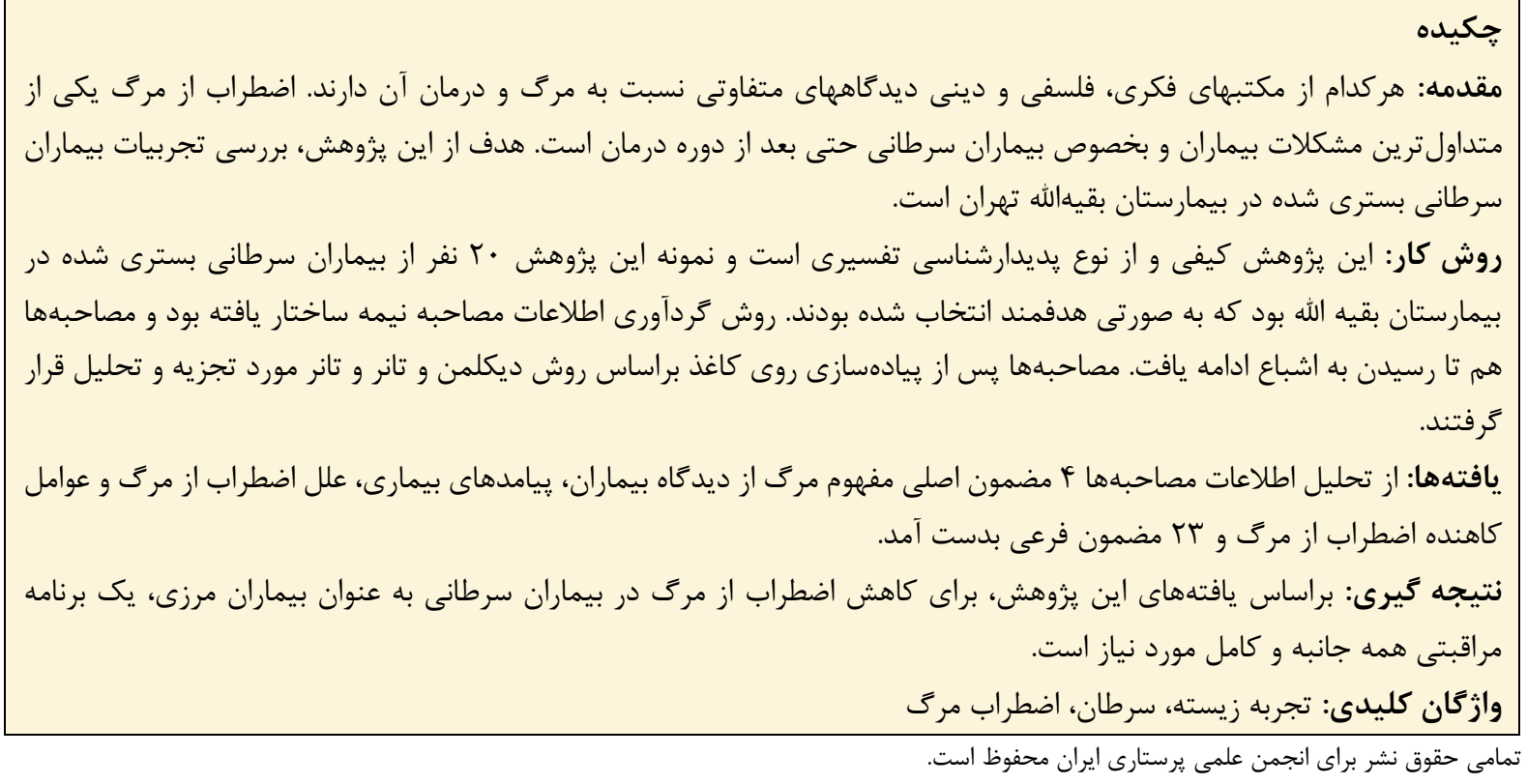
مقدمه

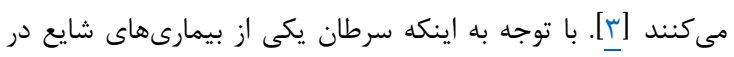

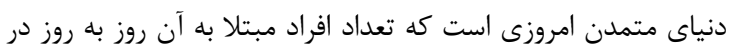

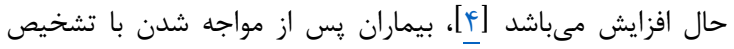

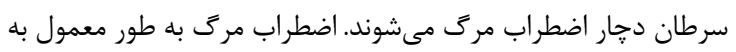

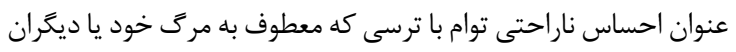

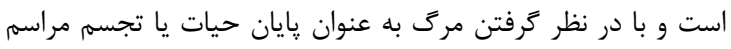

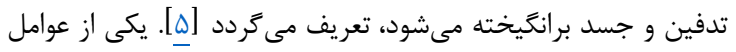

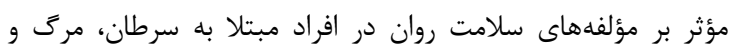

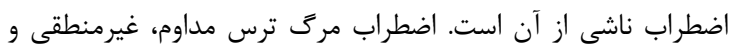

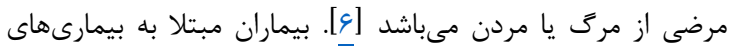

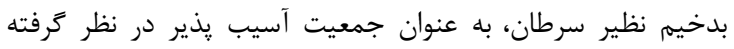

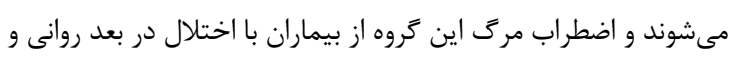

حقديده مركى همواره مورد توجه علوم مختلف قرار كَرفته است. مركى

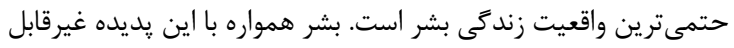

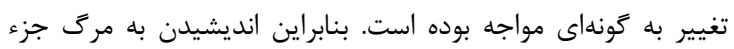

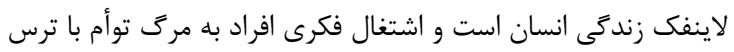

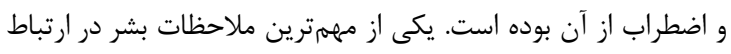

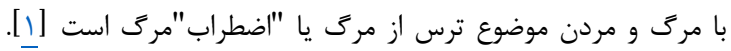

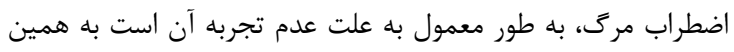

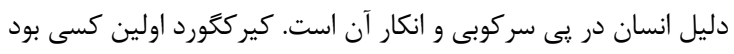

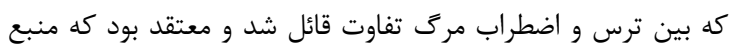

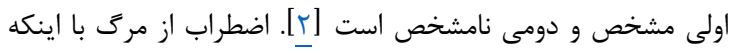

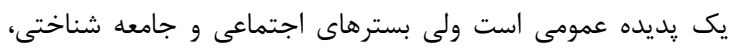

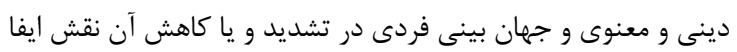


معنى دارى وجود داشت [91 ]. سلاجقه و رقيبى در يزوهشى تحت

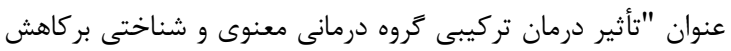

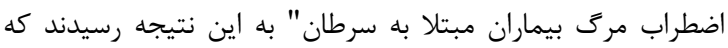

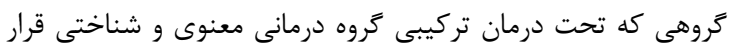

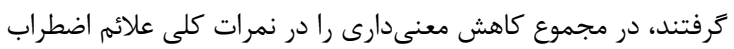

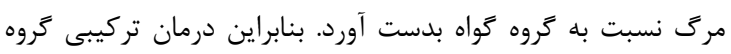

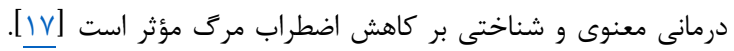

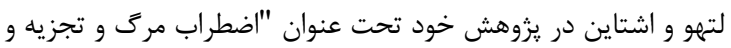

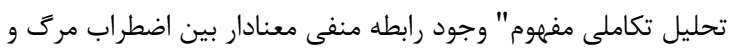

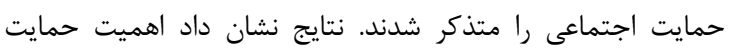

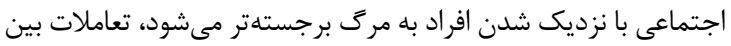

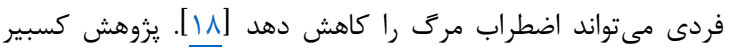

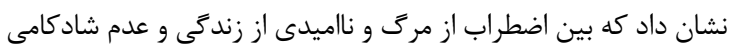

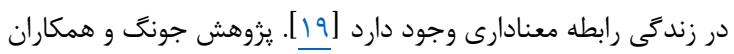

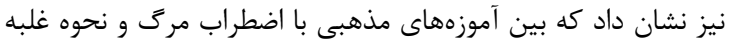

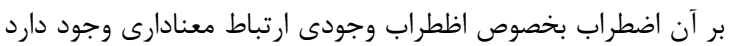

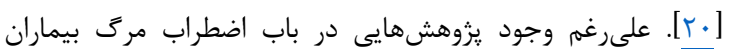

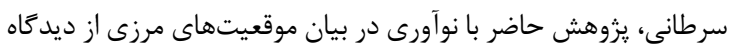

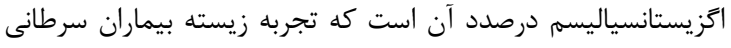

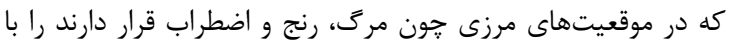

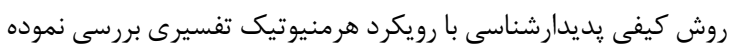

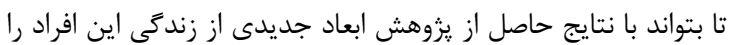

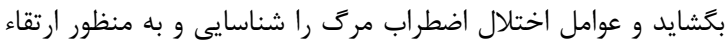

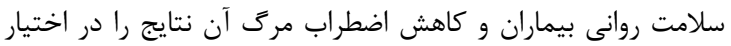
مسئولين سلامت جامعه قرار دهد.

\section{روش كار}

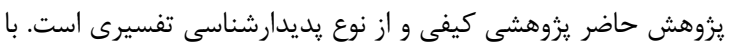

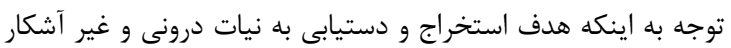

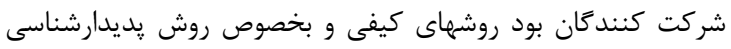

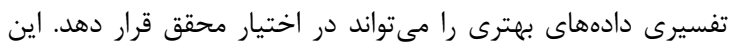

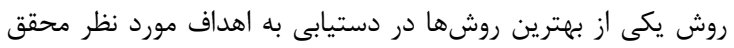

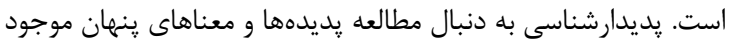

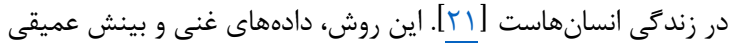

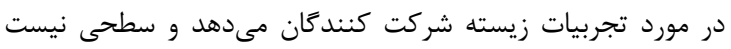

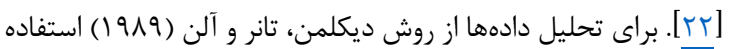

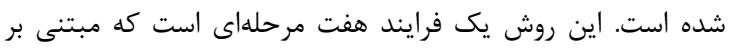

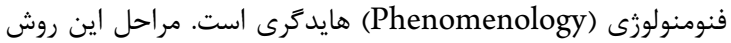

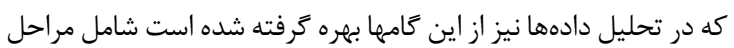

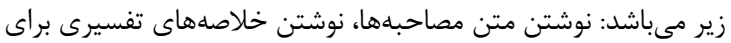
هريك از مصاحبهها، تحليل متون مصاحبها ونها و شناسايى واستخراج

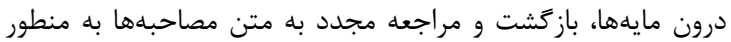

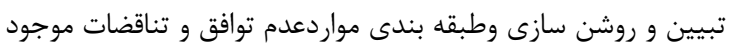

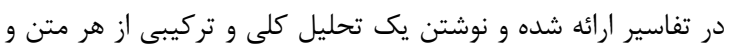

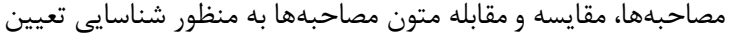
و توصيف معانى مشترك و عملكردها، شناسايى و استخراج الكَوهاى

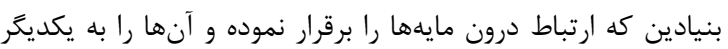

حتى روحى مى تواند زندگى آنان راتحت تأثير قرار دهد [l]]. از طرف

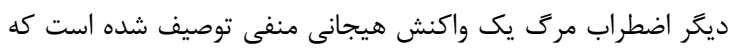

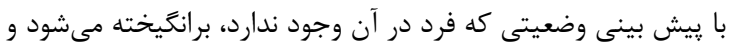

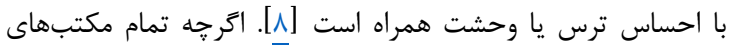

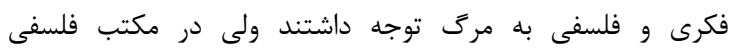

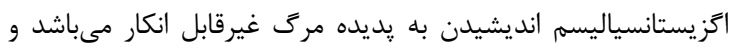

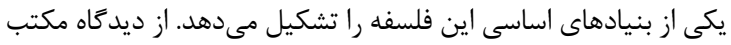

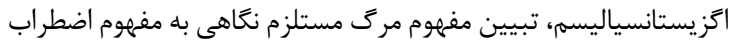

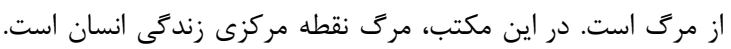

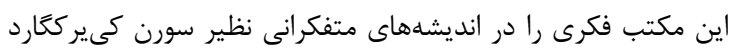

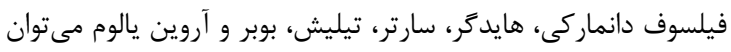

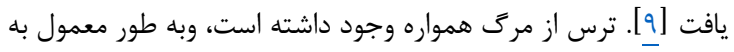

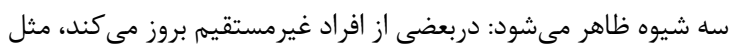

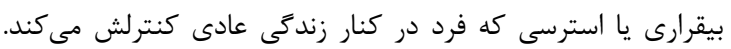

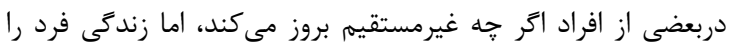

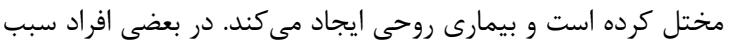

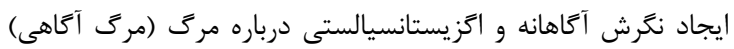
مىشود [1.].

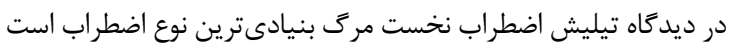

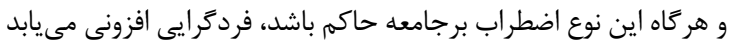

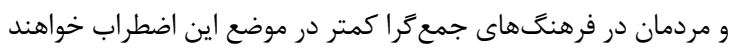

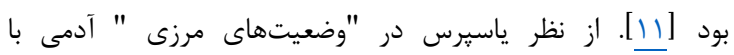

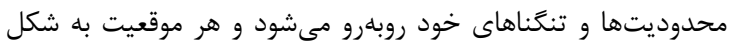

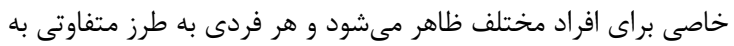

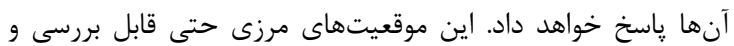

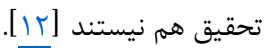

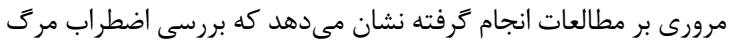

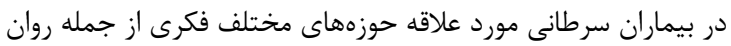

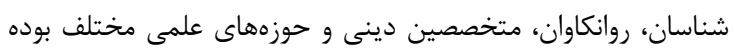

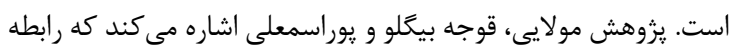

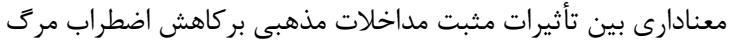

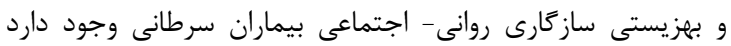

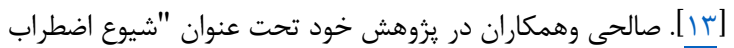

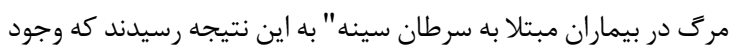

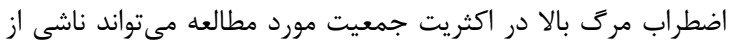

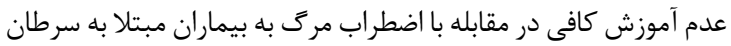

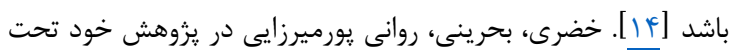

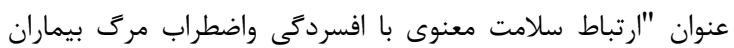

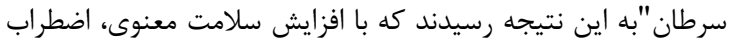

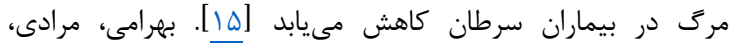

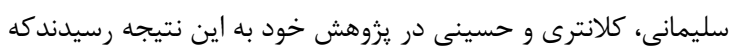

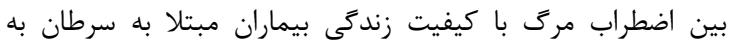

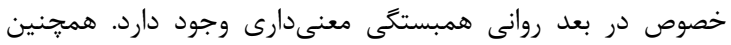

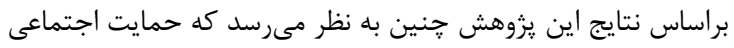

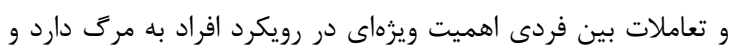

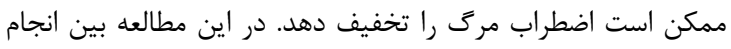

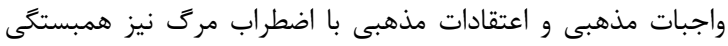


سؤال مشخص شود. با توجه به اينكه مصاحبه ها نيمه ساختار يافته بود

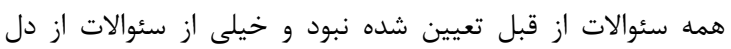

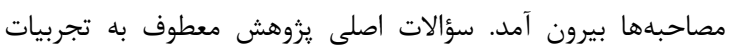

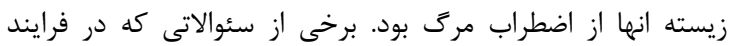

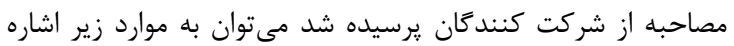

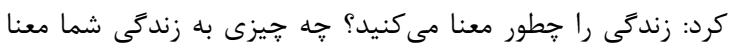

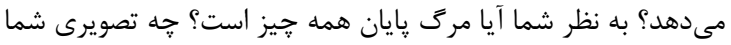

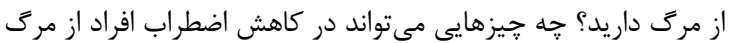

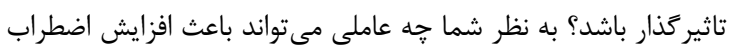

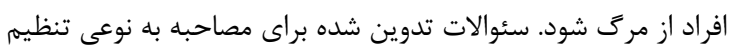

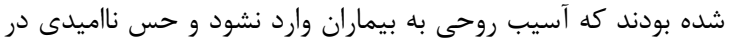

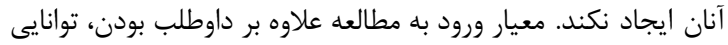

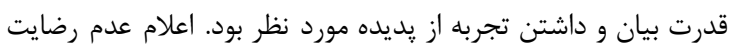

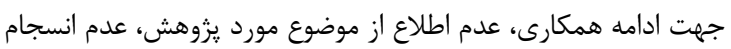

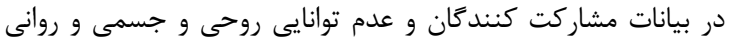

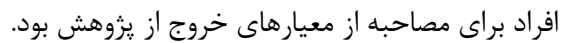

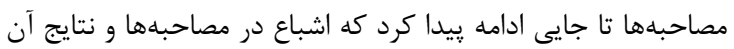

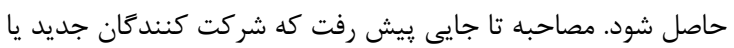

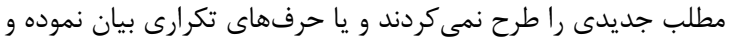

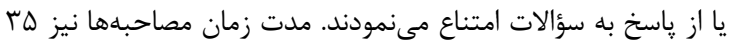

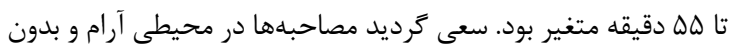

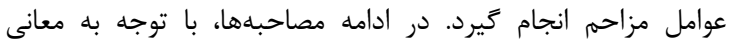

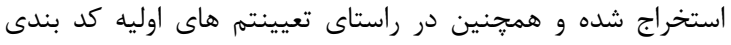

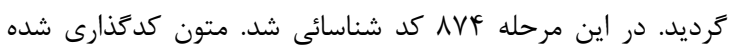

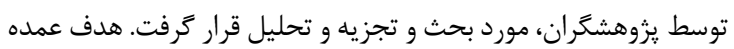

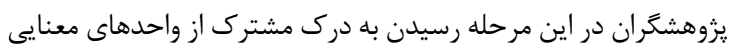

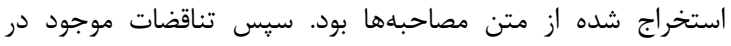

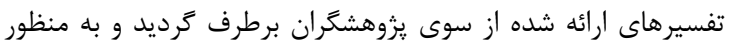

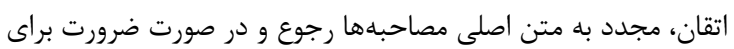

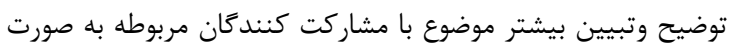

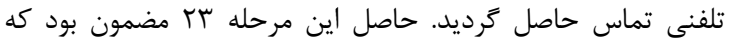

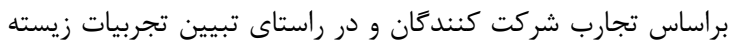

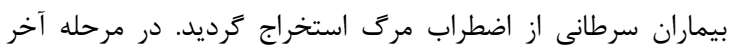

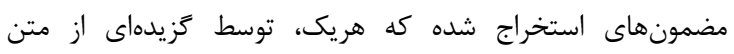

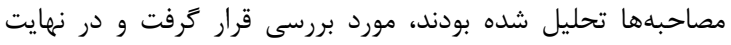

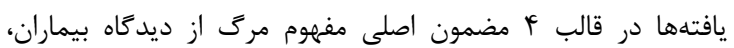

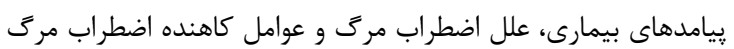

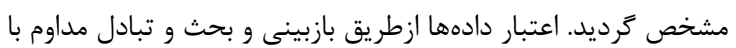
اعضاى مورد مطالعه تقويت گرديد.

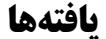

در اين يزووهش بيماران شركت كننده داراى مشخصات زير بودند: به درانه

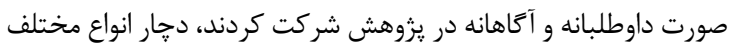

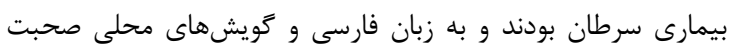

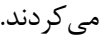

وصل كند و ارائه نسخه بِيش نويس از درون مايهها همراه با كزيدههايى

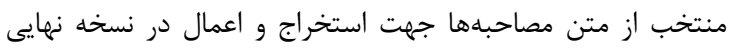

بر اساس روش فوق بعد از انجام هر مصاحبه، ابتدا متن آن روى كاغذ

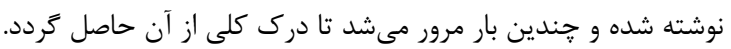

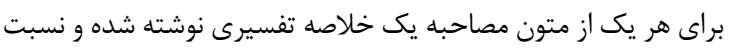

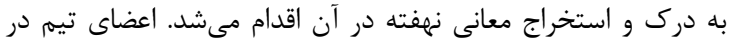

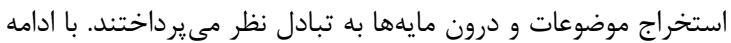

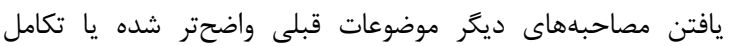

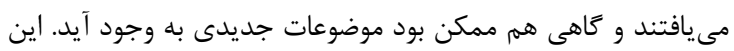

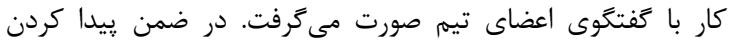

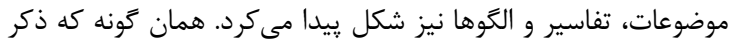

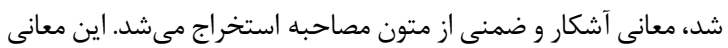

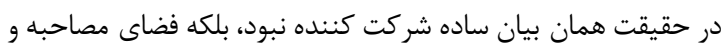

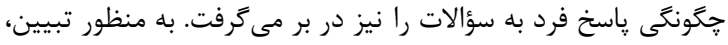

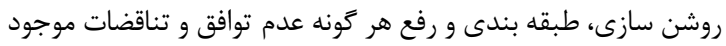

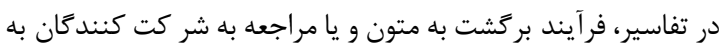

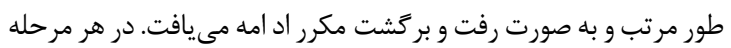

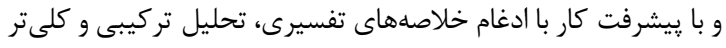

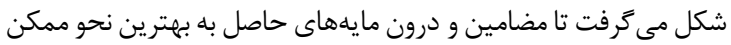

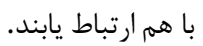

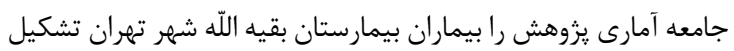

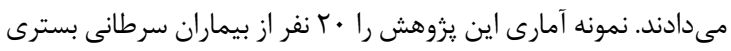

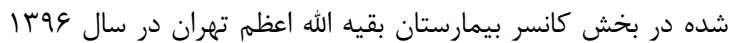

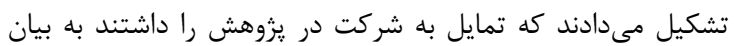

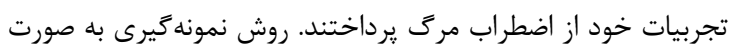

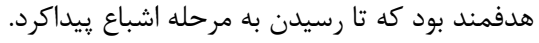

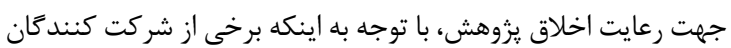

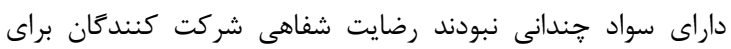

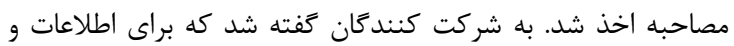

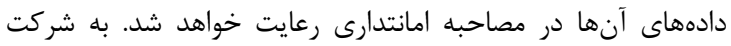

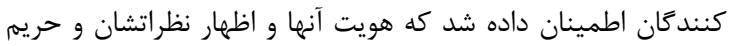

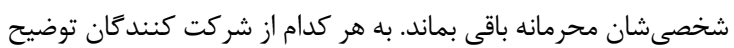

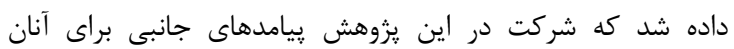

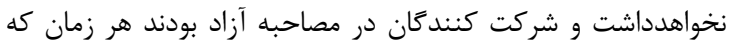

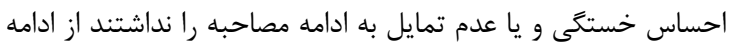

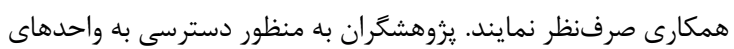

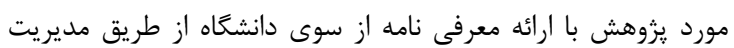

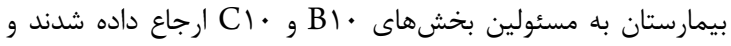

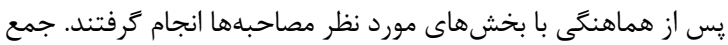

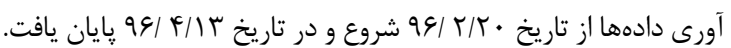

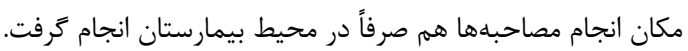

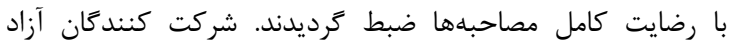

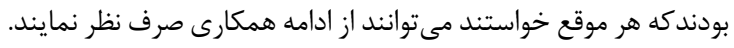

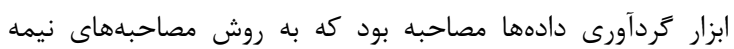

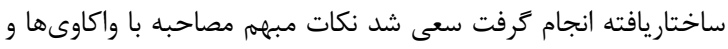

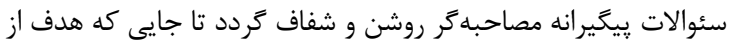


درد و رنج بيمارى به مركى خود راضى شده بودند. برخى از اظهارات شركت كنندگان در زير آورده شده است:

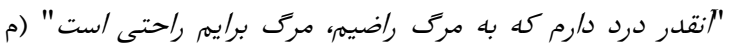

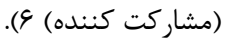

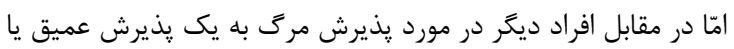

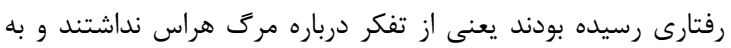
دنبال درك معنى آن بودند.

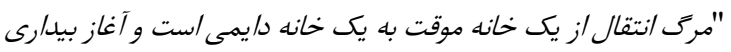

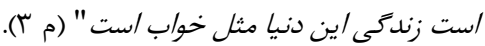

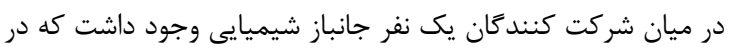

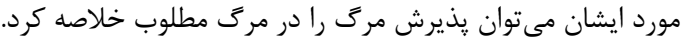

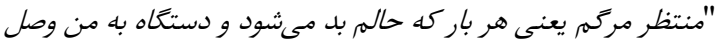

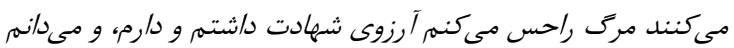
شهيد مىشوم و به معشوقمر معرسم" (م أ). مضمون فرعى: r- تصوير مرى

تصوير مرك يكى از وجوه افتراق تجارب ذهنى شركت كنندكان در

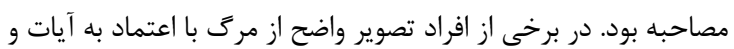

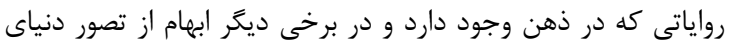

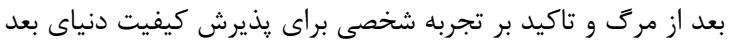

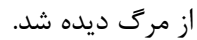

افرادى شركت كننده تصوير مرى را راين مُونه بيان كردند:

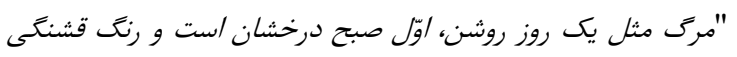

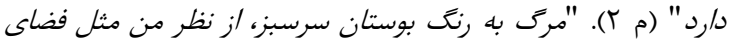

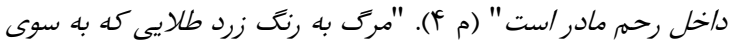

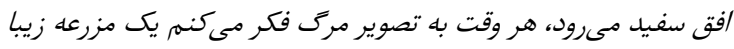

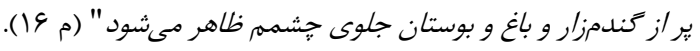

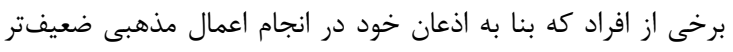

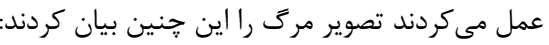

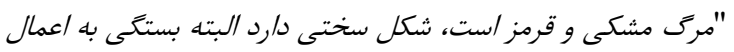

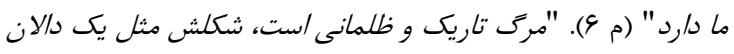

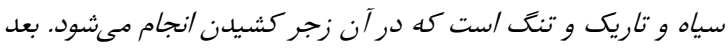

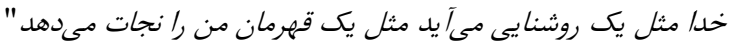

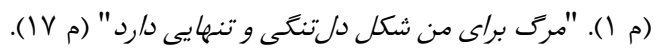

\section{مضمون فرعى: r- عقيده به جهان يس از مرى}

بازگشت و توجه مجدد به خدا از بالاترين مظاهر معنويت مىباشد كه

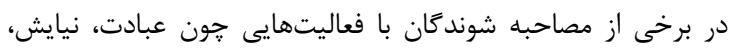

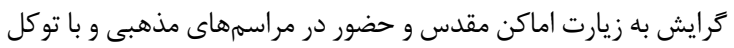

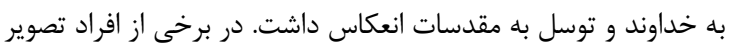

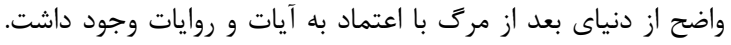

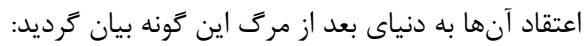

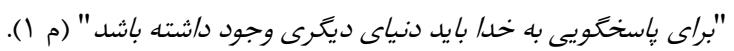

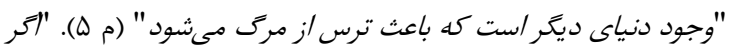

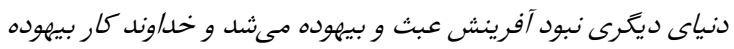

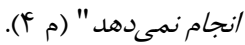
برخى از افراد تصور متفاوت خود را از دنياى بعد از مرى ائ اين خنين

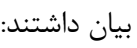

\begin{tabular}{|c|c|c|}
\hline & \multicolumn{2}{|c|}{ حدول ا: مشخصات شركت كنندكان يثوهش } \\
\hline 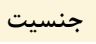 & 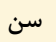 & شركت كننده \\
\hline 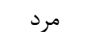 & $9 V$ & 1 \\
\hline 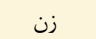 & tr & $r$ \\
\hline 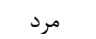 & $\Delta r$ & $r$ \\
\hline 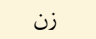 & pq & f \\
\hline 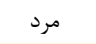 & $\varphi$ & $\Delta$ \\
\hline مرد & $4 \wedge$ & 4 \\
\hline 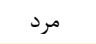 & $\Delta F$ & $\checkmark$ \\
\hline 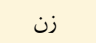 & rᄉ & $\wedge$ \\
\hline 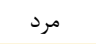 & $\Delta \varphi$ & 9 \\
\hline مرد & 4) & 1. \\
\hline زن & rq & 11 \\
\hline 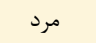 & fF & ir \\
\hline 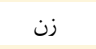 & vi & ir \\
\hline مرد & iv & If \\
\hline مرد & rq & 10 \\
\hline 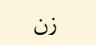 & et & 19 \\
\hline مرد & is & iv \\
\hline 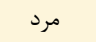 & pr & 11 \\
\hline 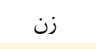 & pq & 19 \\
\hline 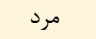 & $\Delta r$ & r. \\
\hline
\end{tabular}

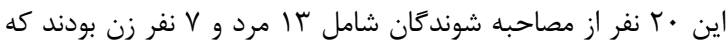

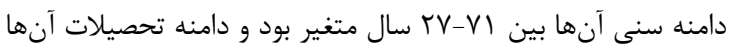

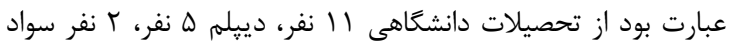

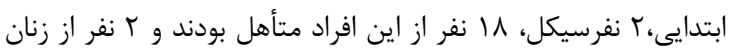

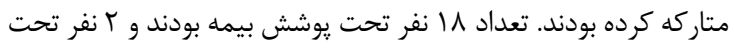

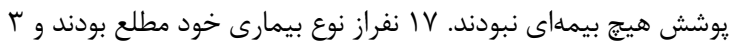

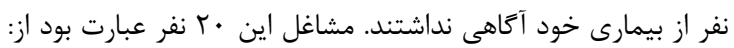

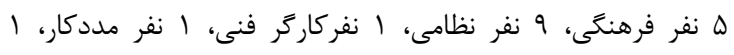

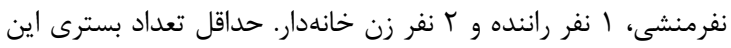

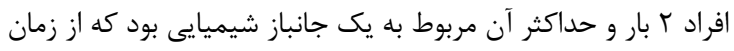

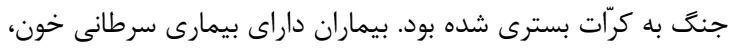

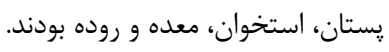

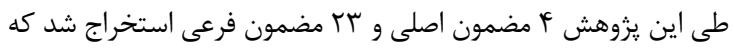
در ادامه به شرح آن هايرداخته مى لَّون:

مضمون اصلى ا: مفهوم مرك از ديدكاه بيماران: يكى از مضامين اصلى كه از بطن مصاحبهها بدست آمد، مفهوم بيماران

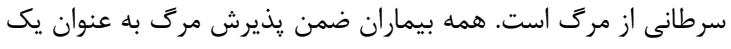

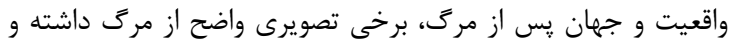

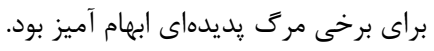

\section{مضمون فرعى: ا-هذيرش مرى}

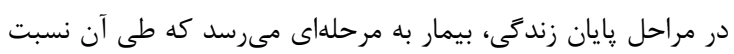

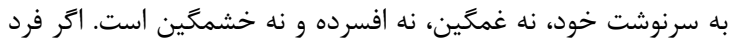

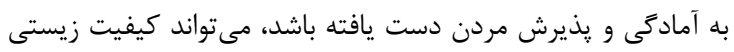

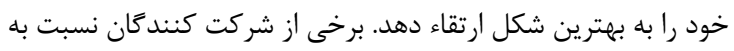

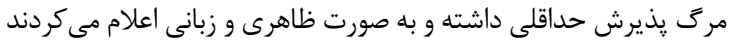

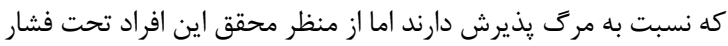


شرايط فعلى و اظهارات برخى از افراد حاكى از اين مسئله مى باشدكه

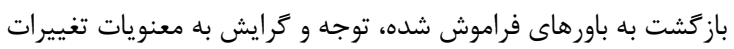

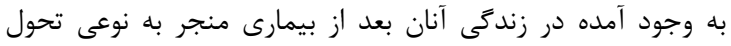

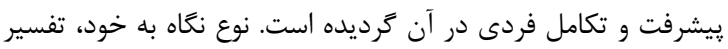

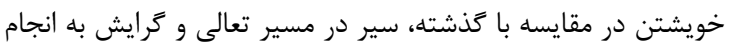

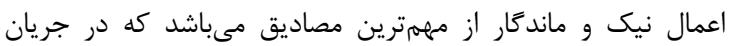

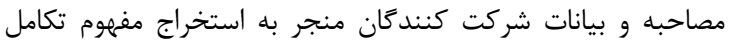

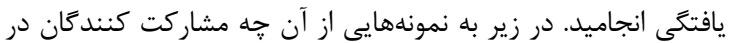

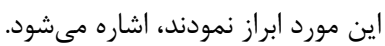

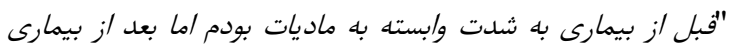

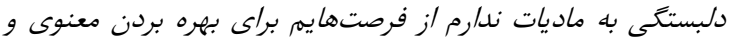

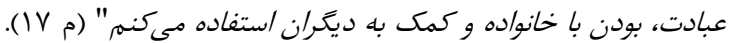

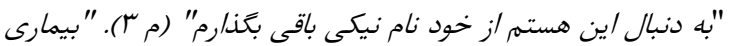

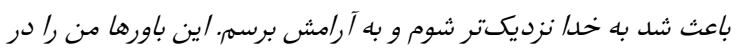

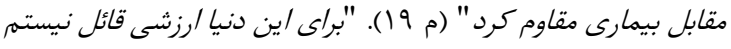

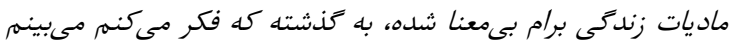

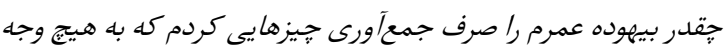

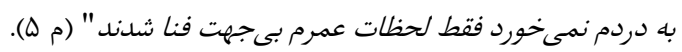

\section{مضمون فرعى F-جبران}

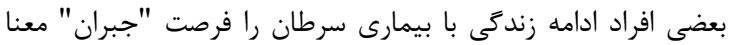

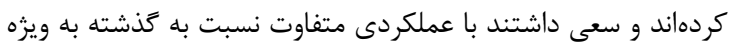

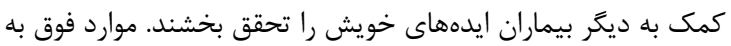

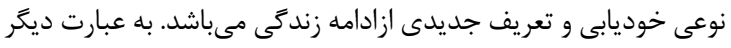

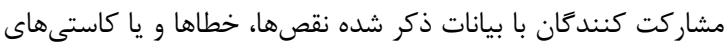

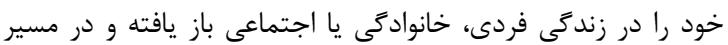

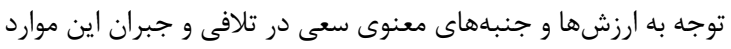

داشتهاند.

بيانات شركت كنندمان در اين خصوص به شرح زير است:

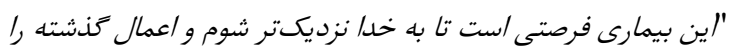

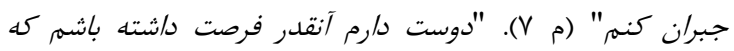

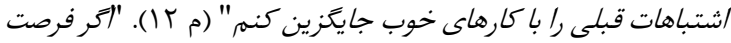

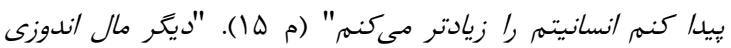

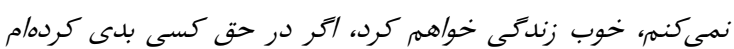

$$
\text { جبران مىكنه" (م 9). }
$$

\section{مضمون فرعى ه- آمادكى براى مردن}

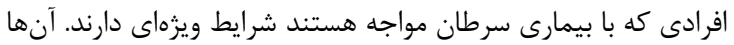

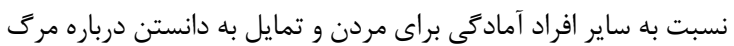

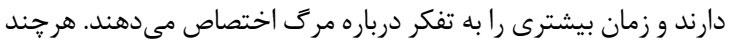

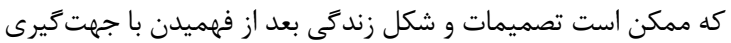

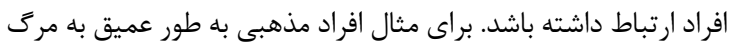

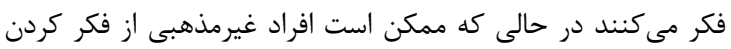

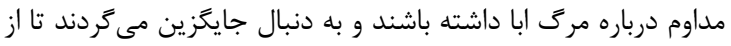

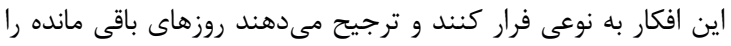

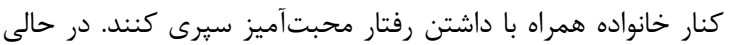

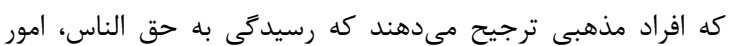

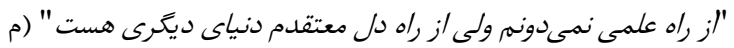

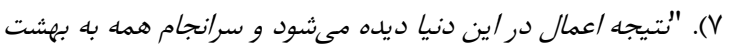

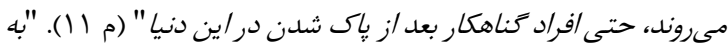

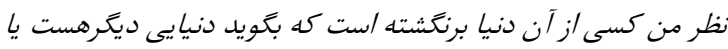

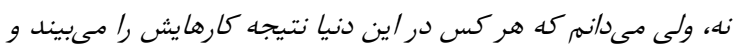

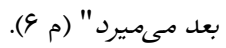

\section{مضمون اصلى ז: ييامدهاى بيمارى:}

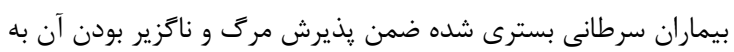

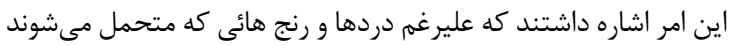

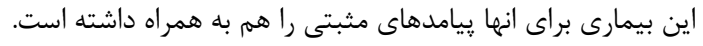

مضمون فرعى ا-كرايش به مذهب

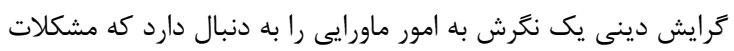

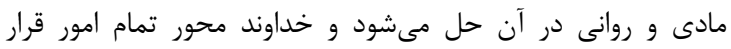

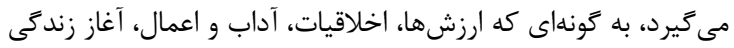

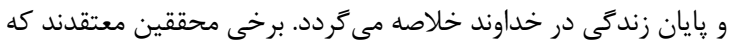

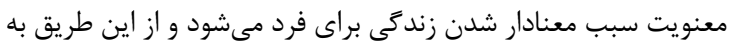

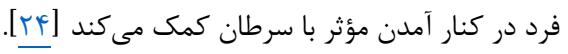

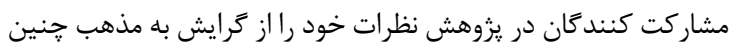

بيان كردند: - مينان

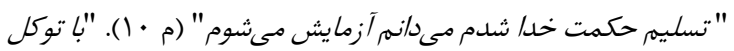

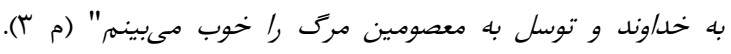

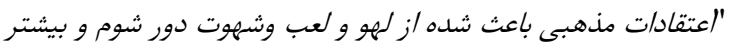
به ياد مركى بيفته" (م مَ).

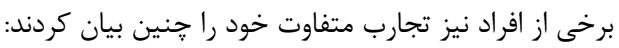

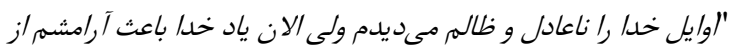

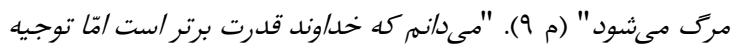

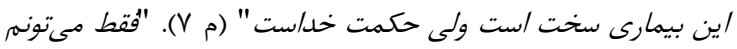

بَّم به بخشش خدا هنَام مردن اعتماد دارم" (م ع). مضمون فرعى r-بخشايشترى بخشايشكَرى به عنوان يك فضيلت مهم اخلاقى مىتواند در دستيابى

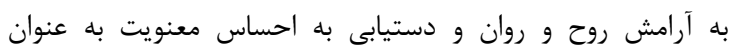

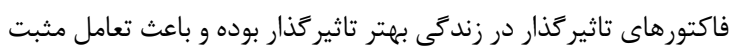

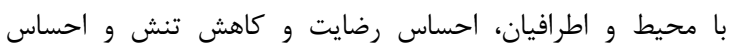

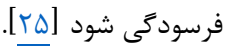

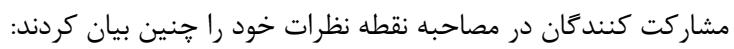

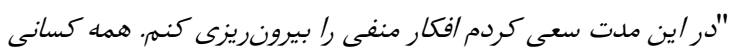

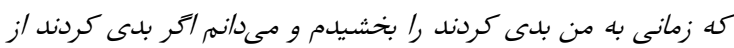

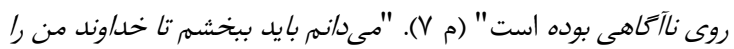

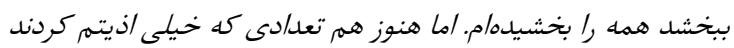

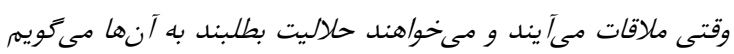

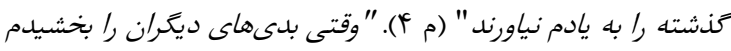

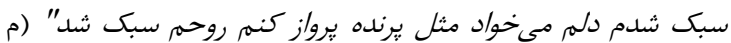


دوستانم نبوند /ز پا در مى آمدم امّا واقعاً نمى دونم تا كى مىتونم با اين وضع دوام بيارم" (م (). مضمون فرعى ب- نعَرانى از آينده خانواده نغرانى يك حالت ذهنى و درونى است كه بطور معمول افراد به

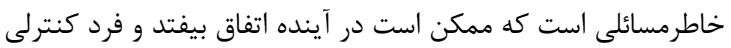

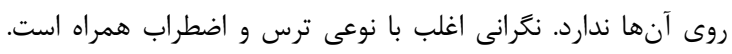

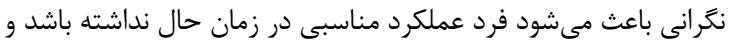

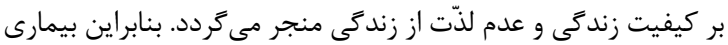

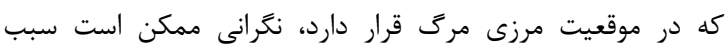

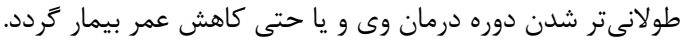

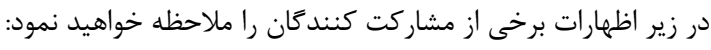

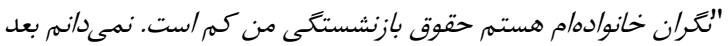

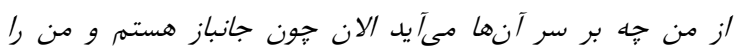

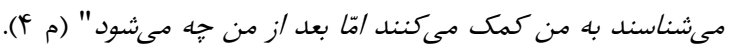

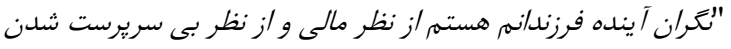

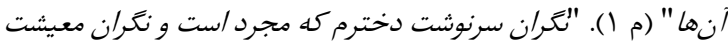

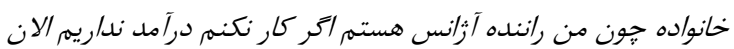

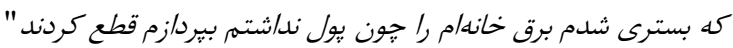

( $)$

\section{مضمون فرعى f-ب اطلاعى از وضعيت بيمارى}

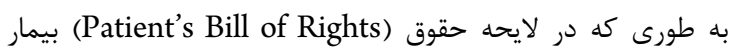

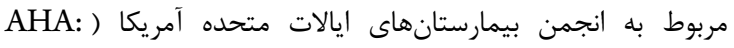

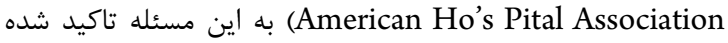
است كه بايد اطلاعات كامل و قابل فهم به صورت معقول توسط كادر

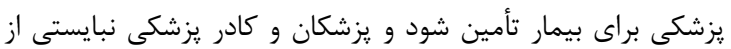

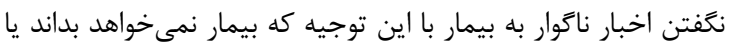

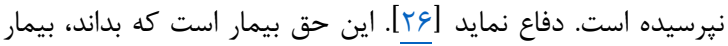

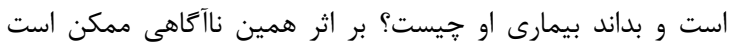

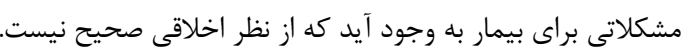
در زير به اظهار نظر مصاحبه شوندگان مي يردازيهم.

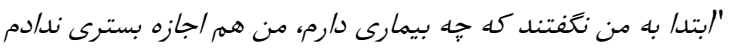

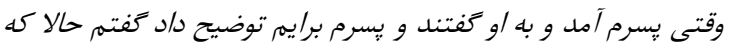

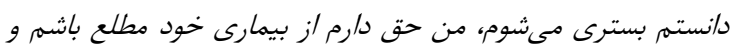

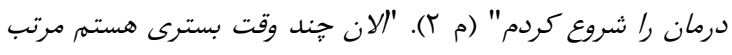

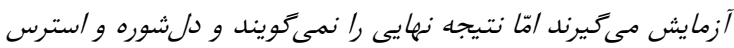

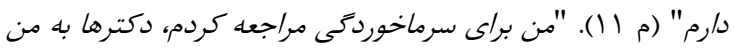

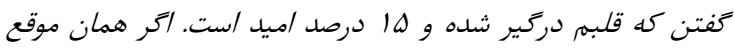

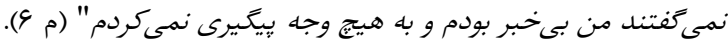

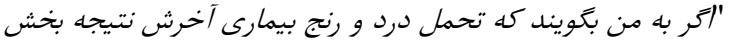

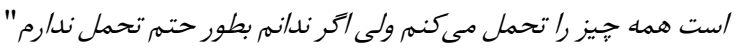

\section{مضمون فرعى ه-ترس از مرى}

انسان ها بطور معمول از جيزهايى كه برايشان ناشناخته است مىترسند.

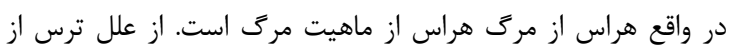

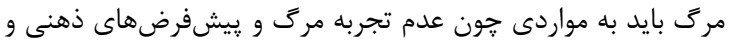

عبادى، جبران زمان كذشته و تنظيم وصيت نامه را انجام دهند. در اين

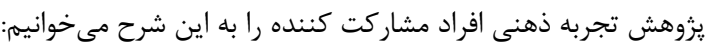

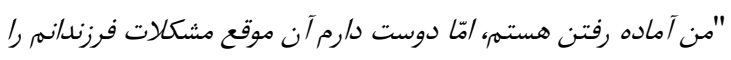

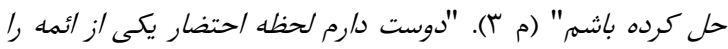

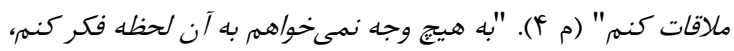

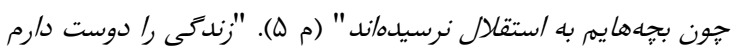
المّا بايد تسليم/راده خداوند شوم" (م ()). مضمون اصلى ؟ّ: علل اضطراب مرى

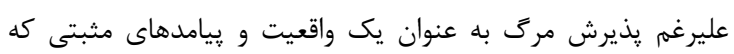

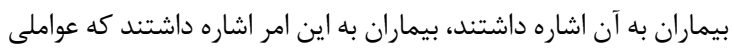

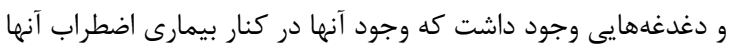
را از مرك تداوم مى وعنشد.

مضمون فرعى ا-درد و رنج

رنجها و سختىها مانند سرطان كه شايد درمانى براى آن نيست،

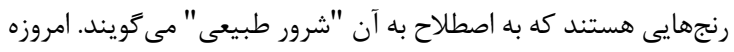

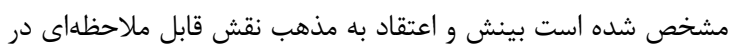

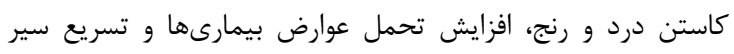

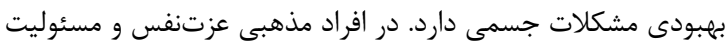

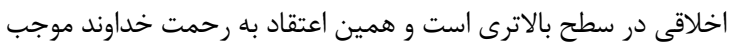

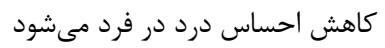

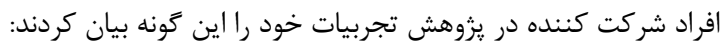

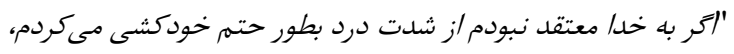

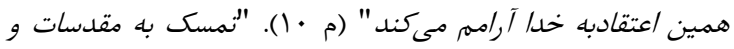

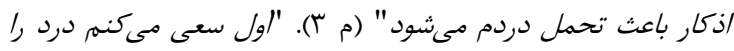

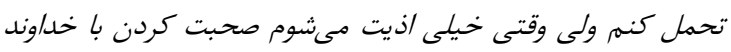

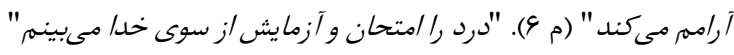

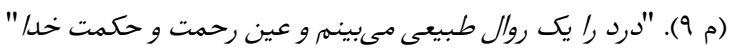

\section{مضمون فرعى ז-وضعيت نابسامان اقتصادى}

وضعيت اقتصادى افراد در درمان سرطان بسيار مؤثر است. زيرا

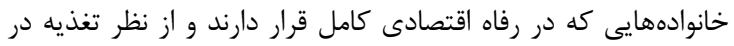
وضعيت مطلوب به سر مىبرند. شرايط درمانى بهترى هم خران خواهند

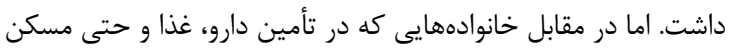

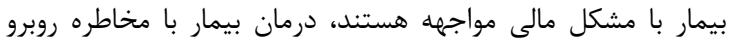
مىشود. برخى ازمشاركت كنندًان در مصاحبه تجربه زيسته خود را اين گونه

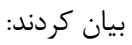
"بايد /ز بيماران حمايت كنند. درمان /ين بيمارى هزينهآور است.

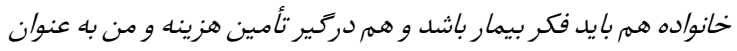

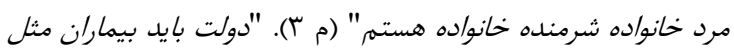

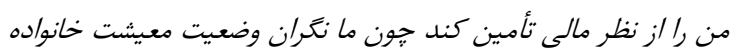

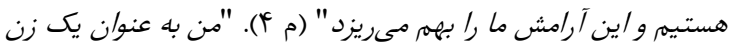

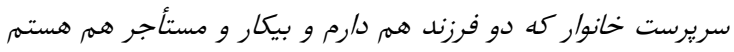

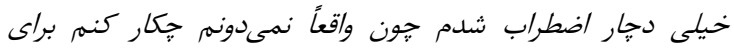

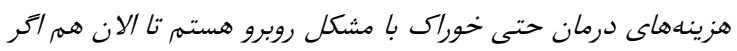


ببرد. اختلال وسواسى، رفتار و انديشههاى اجبارى و درجات متفاوتى

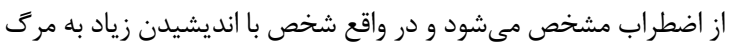

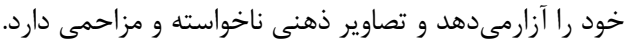

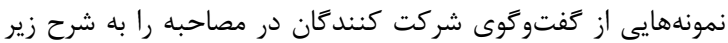
ملاحظه مى كنيد:

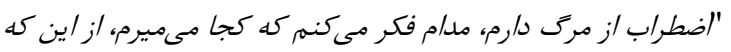

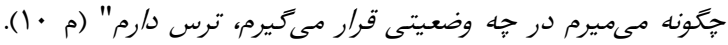

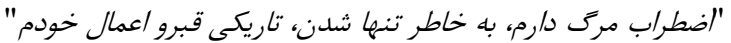

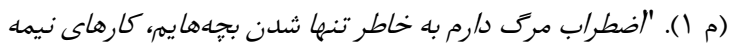

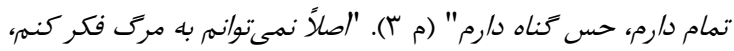

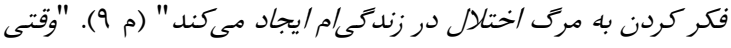

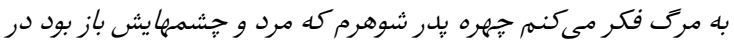

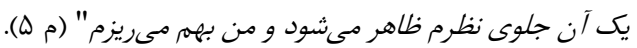

مضمون فرعى ^-بدريختى

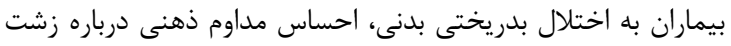

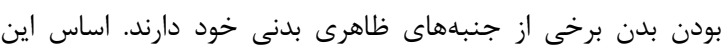
اختلال باور، ترس بيمار است از اين كه ظاهر جذابى ندارد يا حتى نفيه نفرت

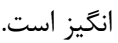

مشاركت كنندكان احساسات خود را از بدريختى جنين بيان كردند:

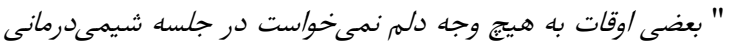

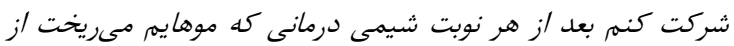

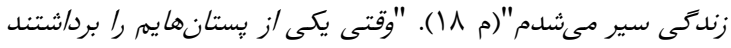

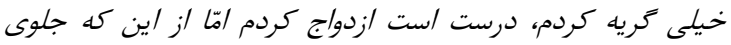

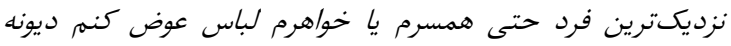

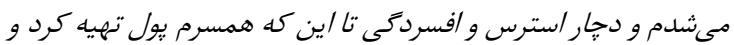

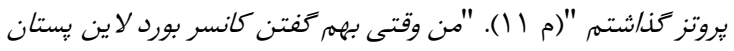

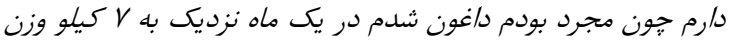

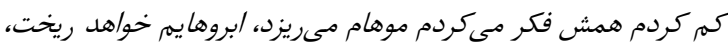

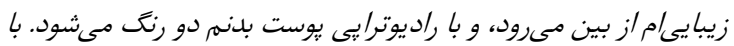

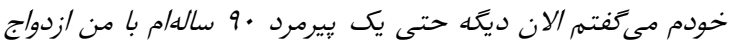

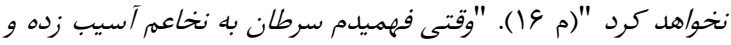

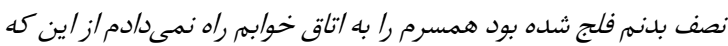

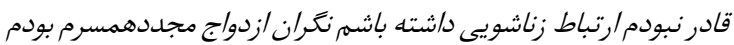

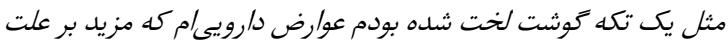

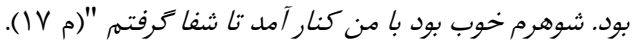

\section{مضمون اصلى f: عوامل كاهنده اضطراب مرك:}

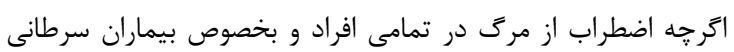

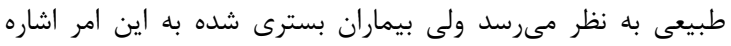

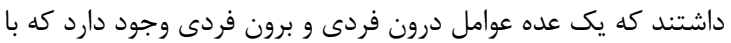

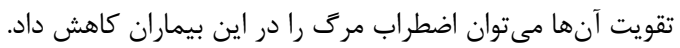

\section{مضمون فرعى 1-اميد به زندكى}

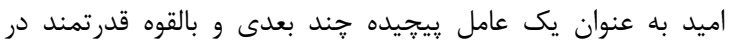

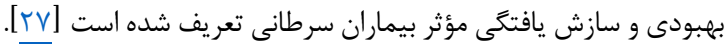

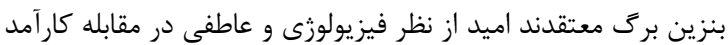

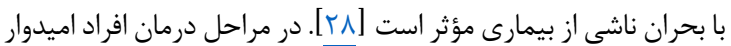

حوادث بعد از مرگ (درون قبر) اشاره كرد. مقايسه توضيحات تجربه

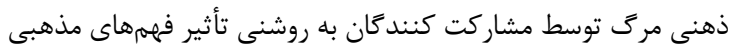

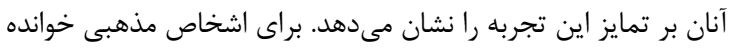

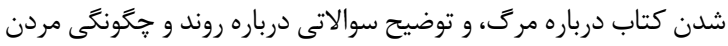

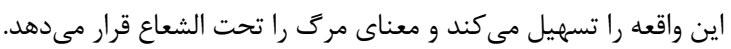

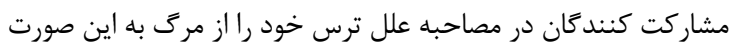

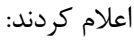
"ترس /ز مرك دارم براى عذاب درون قبر، به خاطر اين كه مى دانم

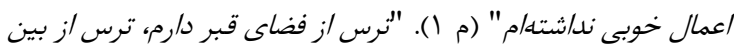

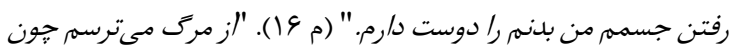

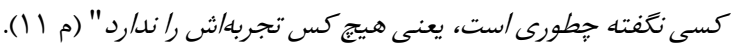

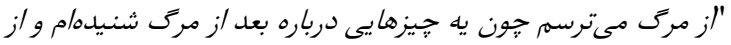

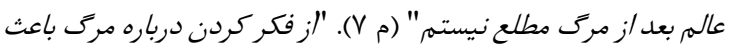

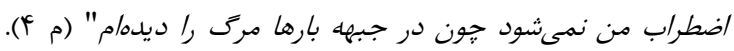

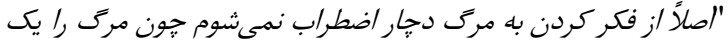

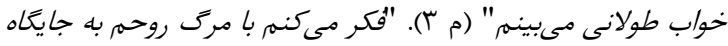

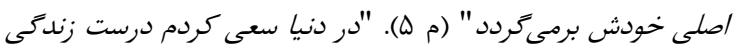

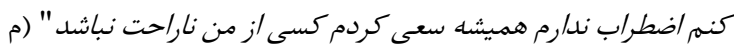

\section{مضمون فرعى 9- فاجعهسازى و نشخوار فكرى} راهبردهاى منفى تنظيم شناختى هيجانى شامل نشخوارفكرى، مقصر

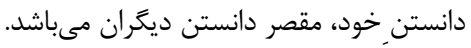

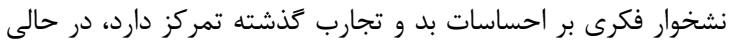

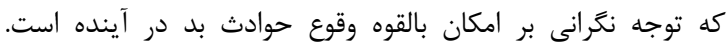

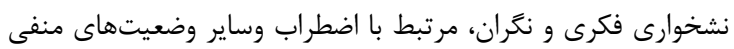

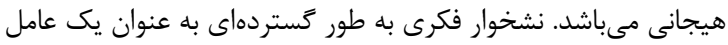

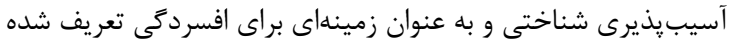

در يزوهش فوق نمونههايى از بيانات شركت كنندكان را در ارتباط با

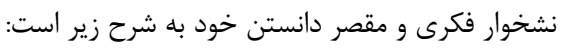

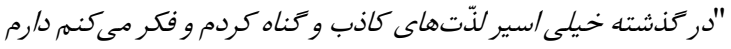

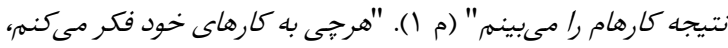

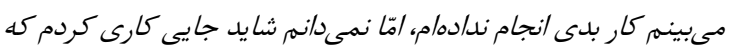

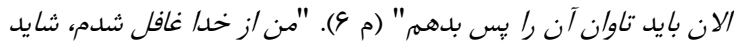

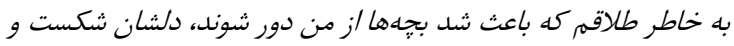

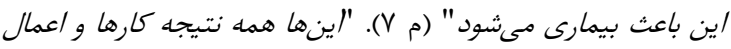

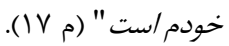

\section{مضمون فرعى V- تداوم فكر كردن درباره مرى}

فكر كردن درباره مرگ ممكن است به شكل تصور و تخيل مرى خود

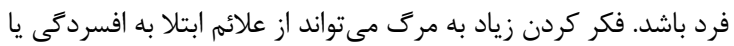

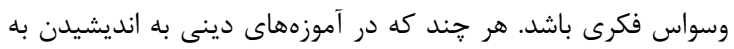

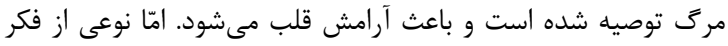

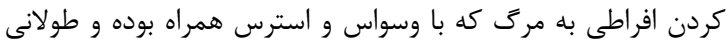

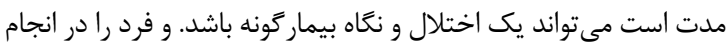

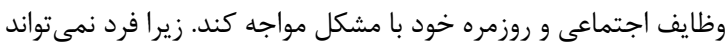

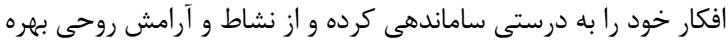


خواهم داشت كه عروسى دختر و نوهايمر را ببينهم" (م ؟). "مريض

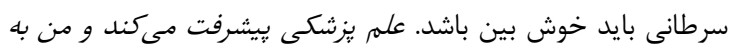
اين زودى خوب خواهم شد" (م V).

\section{مضمون فرعى f-منابع حمايتى}

منابع حمايتى شامل حمايت روحى و روانى توسط خانواده و دوستان،

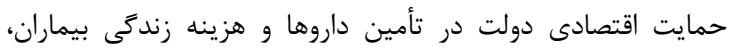

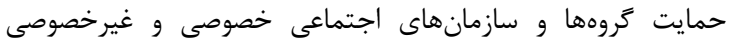

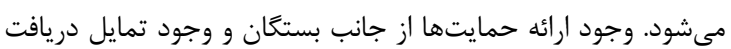

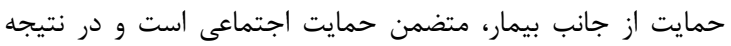

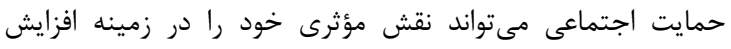

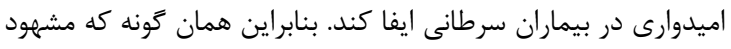

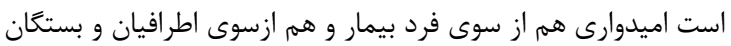

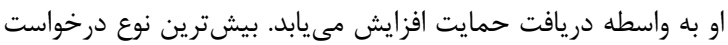

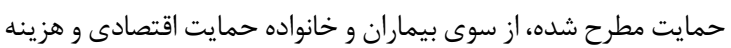

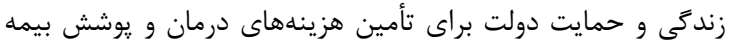
تكميلى و عدم كارايى بيمهها و درخواست حمايت از انجمن هاى خدي خيريه

بودند.

مصاحبه شوندكان حمايت دريافت شده از جانب خانواده و دوستان ران

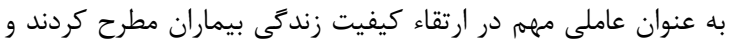

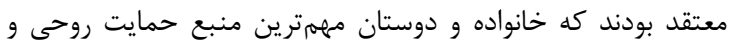
روانى مىباشند.

مصاحبه شوندكان نظرات خود را درخصوص امكانات بيان كردند:

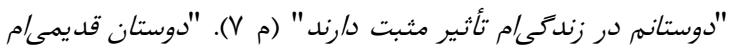

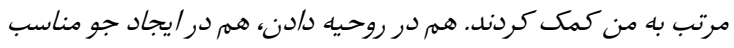
در منزل، هم در هزينهایى درمانى" (م (1). بيشترين نوع درخواست حمايت مطرح شده ازطرف بيمارئهان، دمان، حمايت اقتصادى بود.

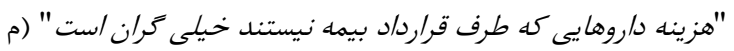

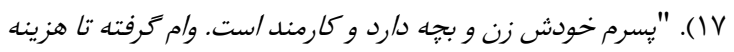

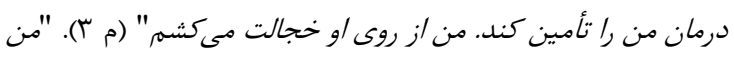

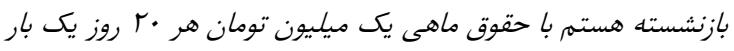

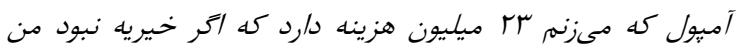

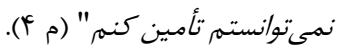

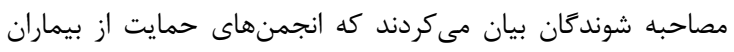

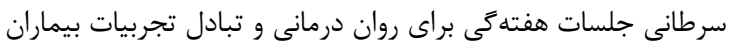
باله يكديغر تشكيل دهند.

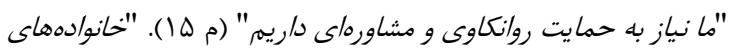

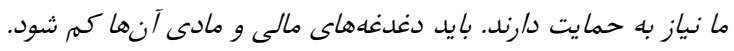

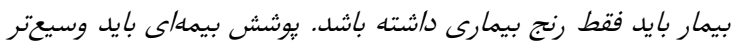

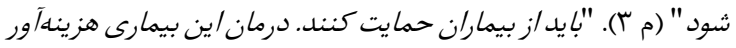

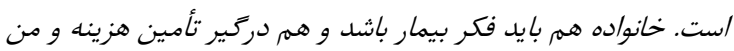

به عنوان مرد خانواده شرمنده خانواده هستهر" (م باند).

\section{مضمون فرعى ه-امكانات}

كمبود بيمارستانهاى دولتى در كيفيت زندگى بيماران در مرحله

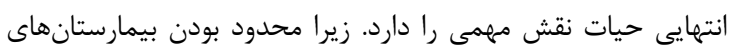

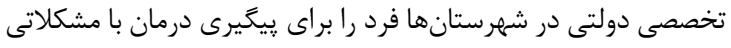

در تحمل درمانهاى طولانى و دردناى و عوارض شيمىدرمانى يا

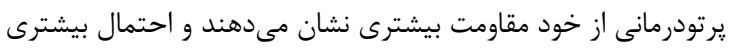

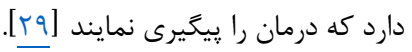

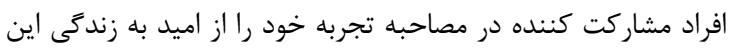
كونه بيان مى كنند:

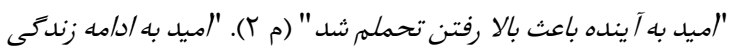

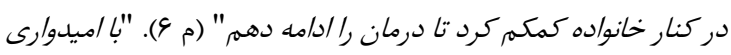

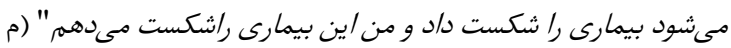

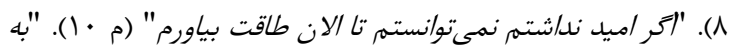

رحمت و نعاه خدا /ميد دارم" (م Y I ).

\section{مضمون فرعى r-معنادارى و كيفيت زندكى}

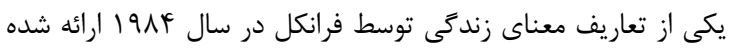

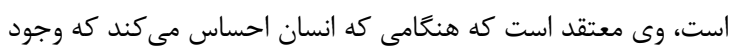

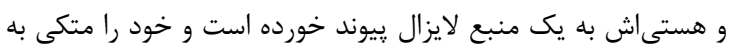

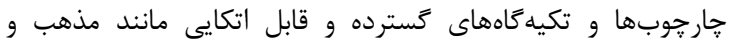

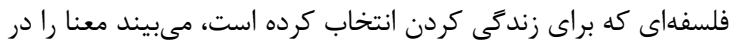

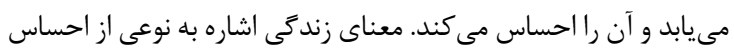

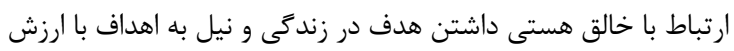
و رسيدن به تكامل دارد. معناى زندگى در اصل ماهيت شناختى دارد، جرا كه دارد در برد بردارنده

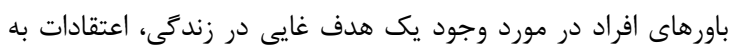

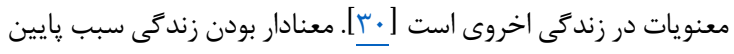

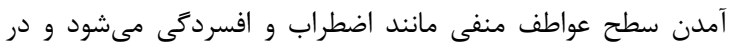

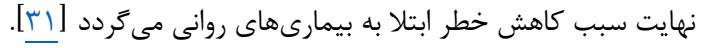

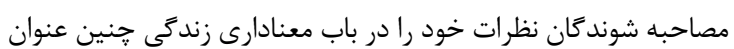
كردند: "ان خه باعث معنابخشى به زندكى من مىشود وجود همسر وفرزندانم

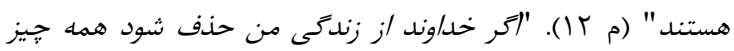

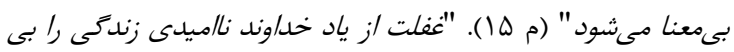

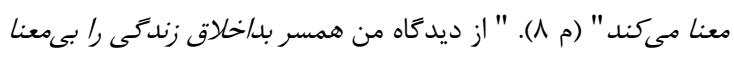

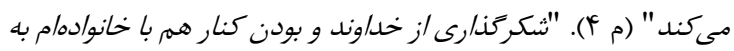
زندكى من معنا مى مهد" (م بام).

\section{مضمون فرعى ب-خوشبينى به آينده}

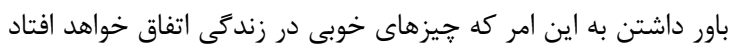

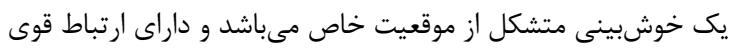

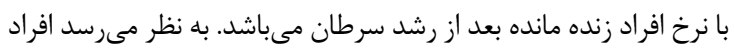

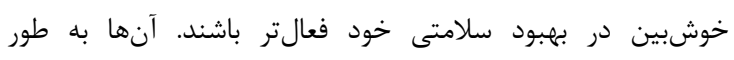

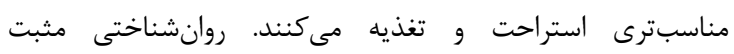

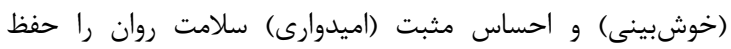

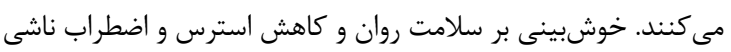
از سرطان تأثير به سزايى دارد. در تحقيق فوق شركت كنندكان خوشبينى خود به به آينده را راين كونه

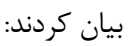

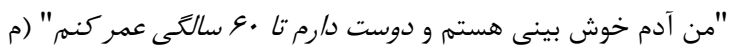

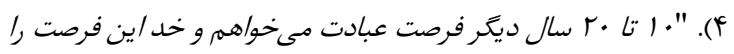

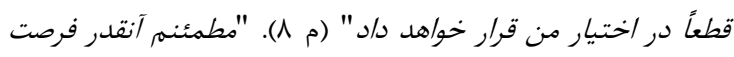


انجمنهايى تشكيل بدهند كه ما بيماران سرطانى دور همر جمع بشويم

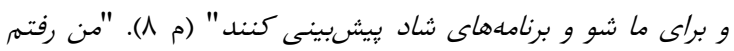

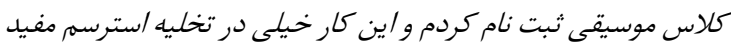

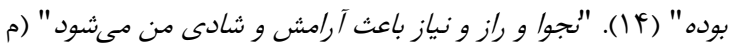

جدول r: مضامين اصلى و فرعى تجارب زيسته افراد از اضطراب مرك

\begin{tabular}{|c|}
\hline مضامين فرعى \\
\hline مفهوم مرك از ديدكًاه بيماران \\
\hline 1- 1-ذيرش مركى \\
\hline r-تصوير مرى \\
\hline r-عقيده به جهان پِ از مركى \\
\hline ي پيامدهاى بيمارى \\
\hline | ا-كرايش به مذهب \\
\hline r-بخشايش \\
\hline r-كرايش به كمالجويى \\
\hline 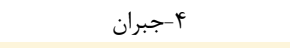 \\
\hline هـ-آمادكى براى مردن \\
\hline علل اضطراب مرى \\
\hline 1 \\
\hline ץ-وضعيت نابسامانى اقتصادى \\
\hline r-نكرانى از آينده خانواده \\
\hline |+-بىاطلاعى از وضعيت بيمارى \\
\hline ه- ترس از مرى \\
\hline צ-فاجعهسازى و نشخوار فكرى \\
\hline Y-تداوم فكر درباره مرك \\
\hline ^-بدريختى \\
\hline عوامل كاهنده اضطراب مرىى \\
\hline 1-اميد به زندگى \\
\hline ז-معنادارى و كيفيت زندگى \\
\hline r r-خوشبينى به آينده \\
\hline F أ-منابع حمايتى \\
\hline 四 \\
\hline 9-خدمات مشاور ماى \\
\hline Vادكامى V \\
\hline
\end{tabular}

بحث

يزوهش حاضر بررسى تجربيات زيسته بيماران سرطانى بيمارستان بقيه

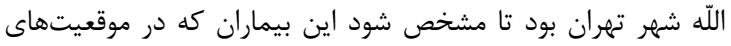

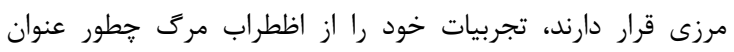

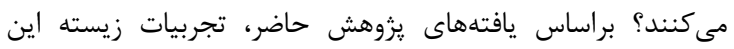

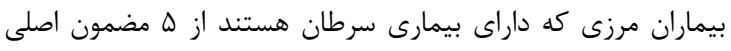

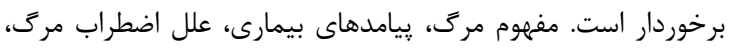

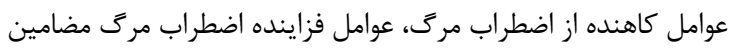

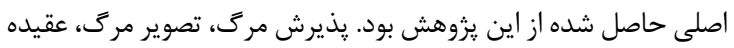

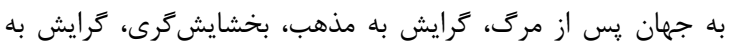

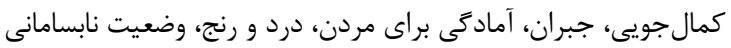

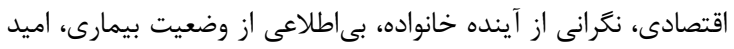

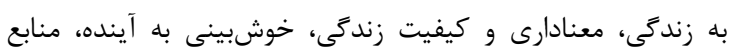

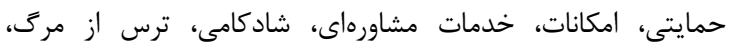

مانند دورى از خانواده و نداشتن ملاقات كننده و يا سركردانى همراه

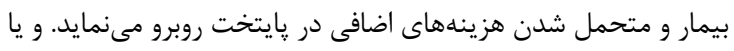

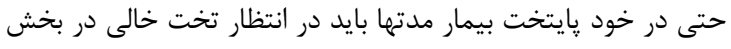

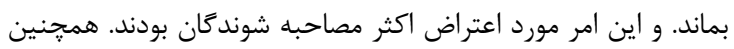

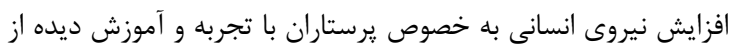

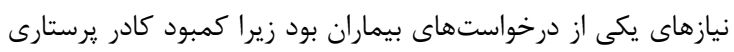

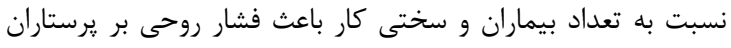

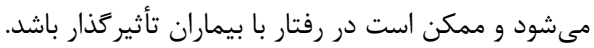

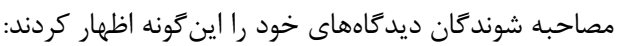

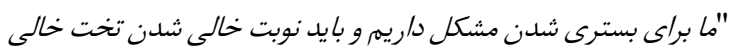

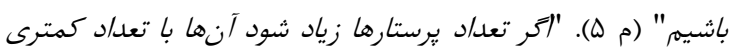

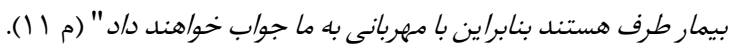

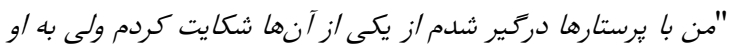

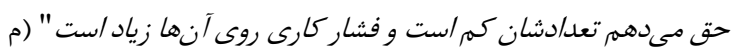

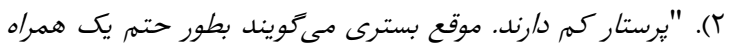

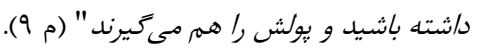

\section{مضمون فرعى צ- خدمات مشاورهاى}

روانشناسان معتقد بودند يذيرش بيمارى به خصوص بيمارى لاعلاج

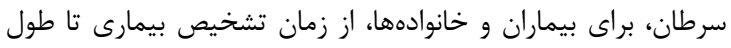

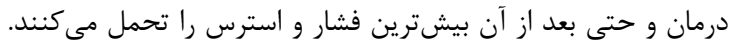

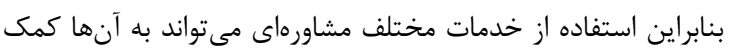

$$
\text { مؤثرى بنمايد. }
$$

افراد شركت كننده در مصاحبه نظر خود رايد را در رابطه با خدمات مشاورهاى اين تونه بيان كردند.

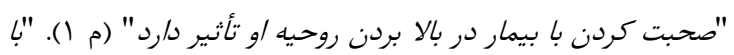

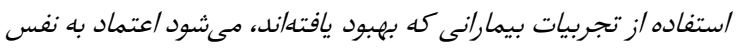

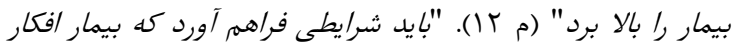

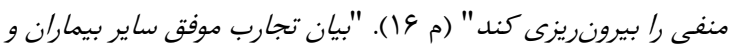

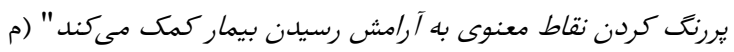

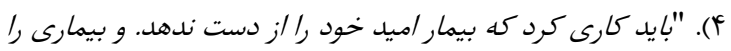

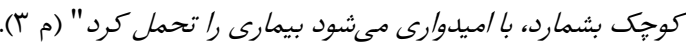

مضمون فرعى V- - شادكامى

احساس رضايت و شادكامى در زندكى روزمره، يكى از مهرمترين عوامل

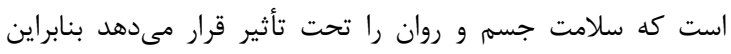

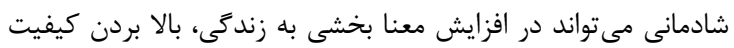

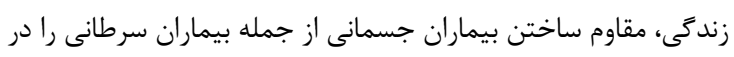

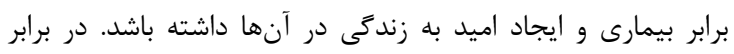

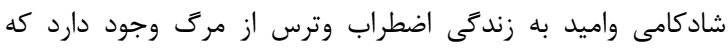

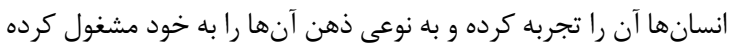

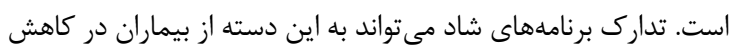

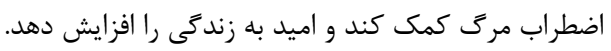

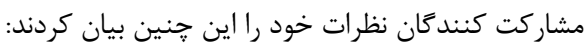

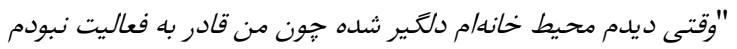

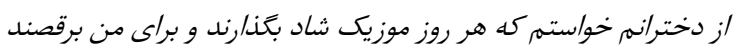

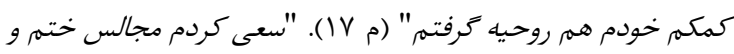

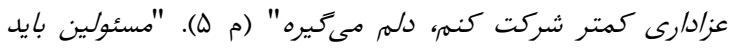




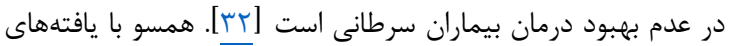

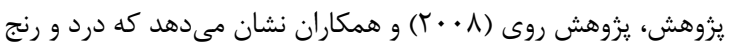

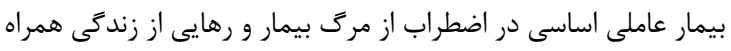

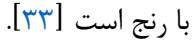

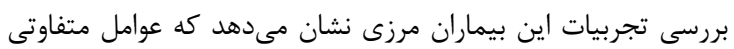

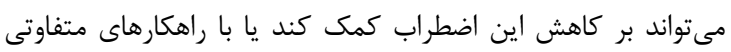

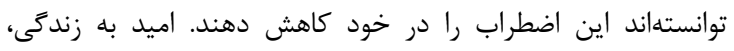

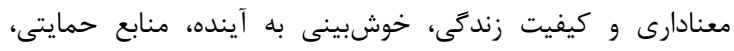

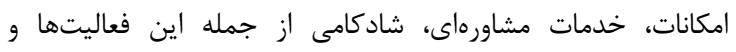

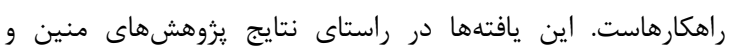

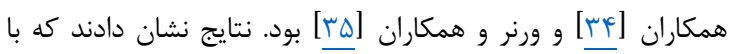

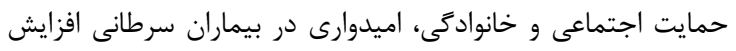

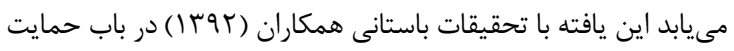

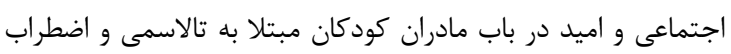

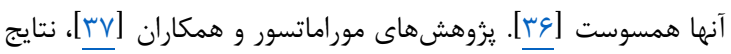

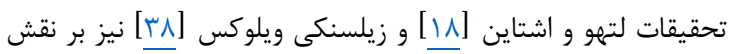

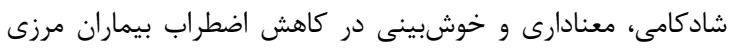

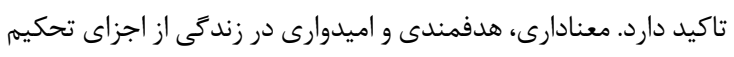

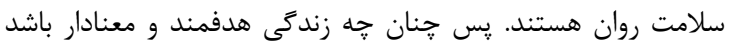

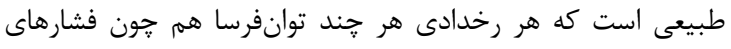

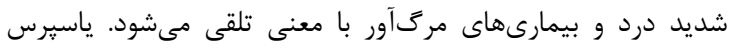

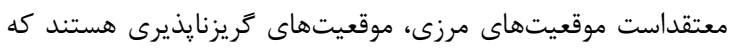

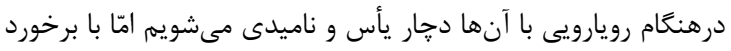

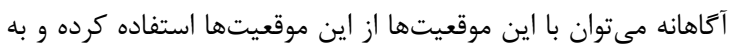

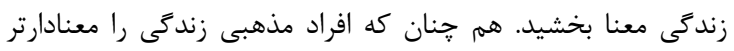

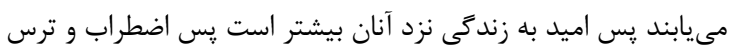

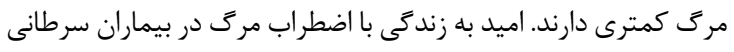
رابطه معكوس دارد.

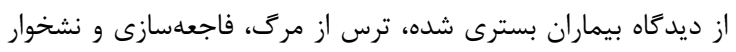

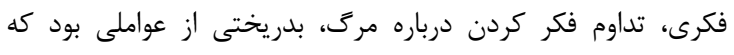

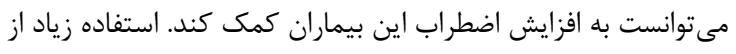

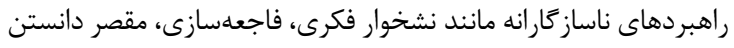

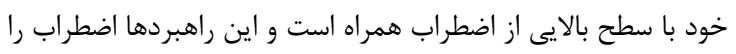

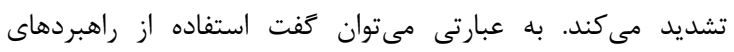

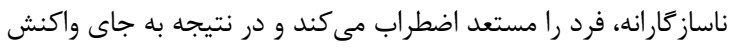

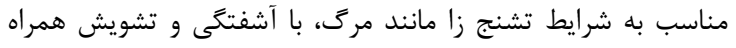

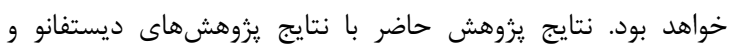

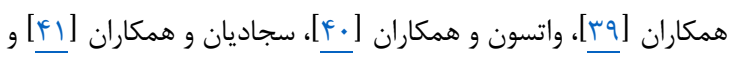
كسبير [19] همسو مىباشد.

\section{نتيجه تيرى}

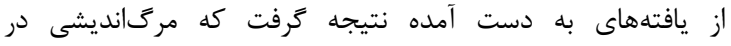

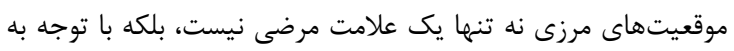

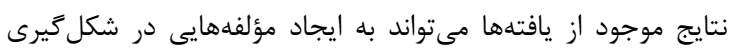

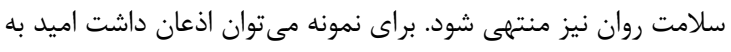

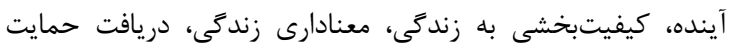

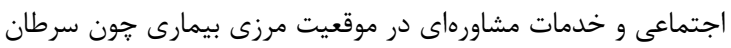

فاجعهازى و نشخوار فكرى، تداوم فكر كردن درباره مركَ، بدريختى

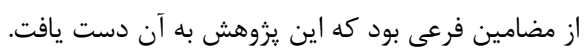

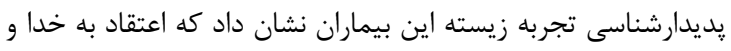

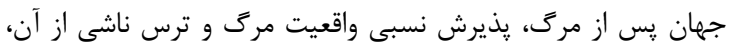

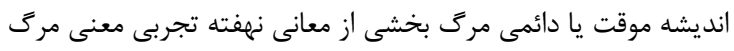

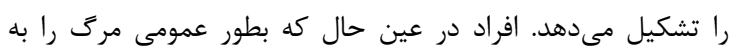

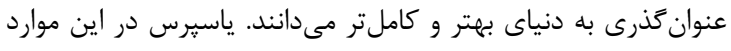

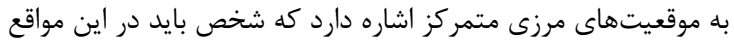

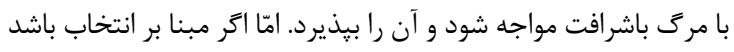

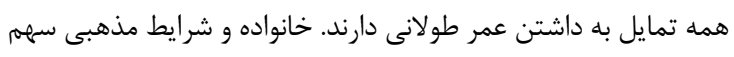

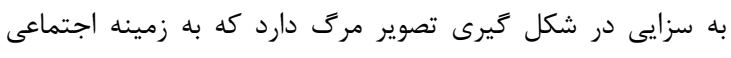

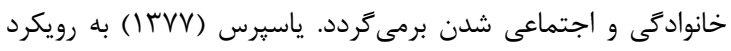

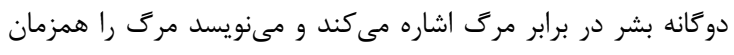

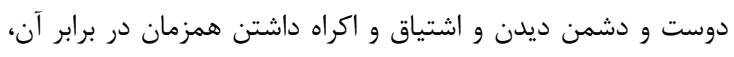

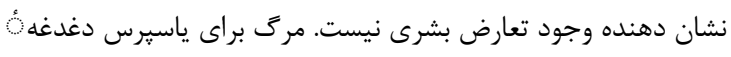

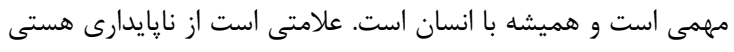

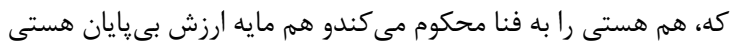

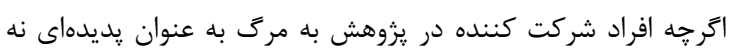

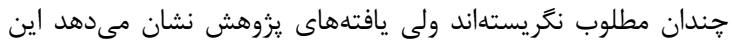

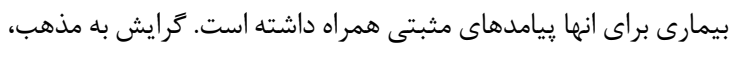

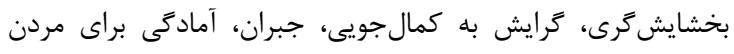

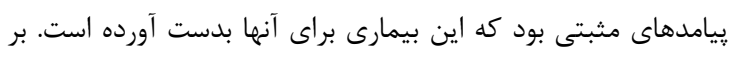

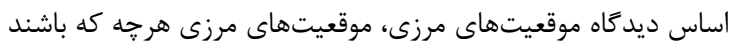

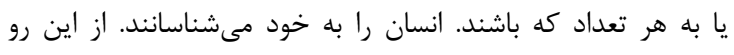

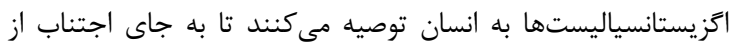

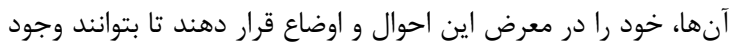

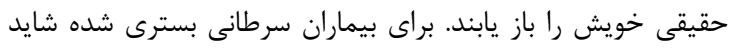

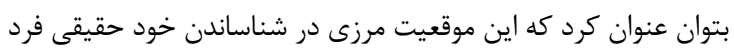

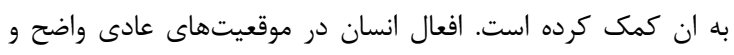

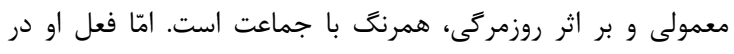

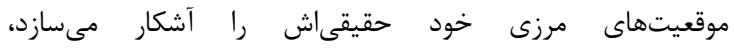

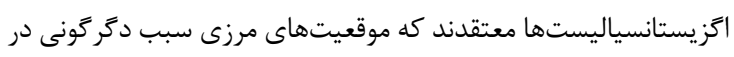

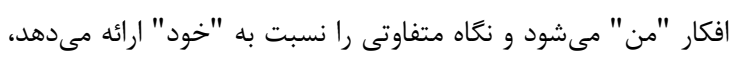

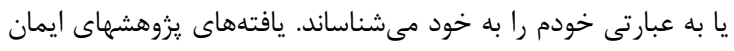

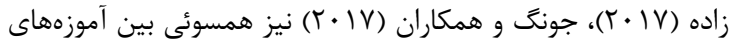

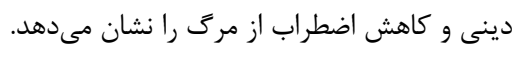

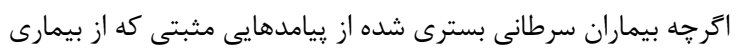

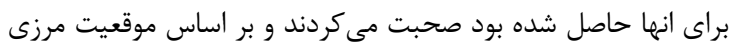

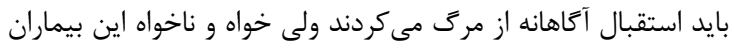

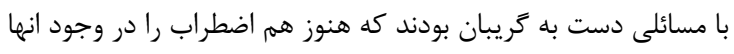

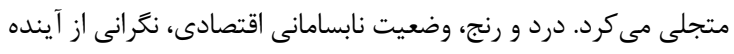

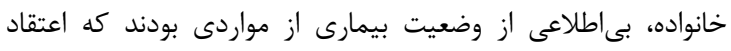

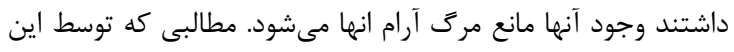

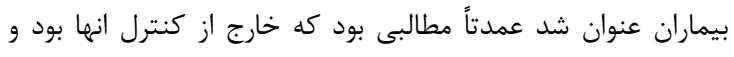

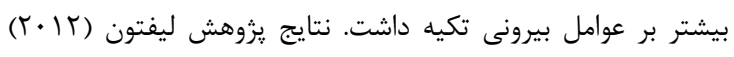

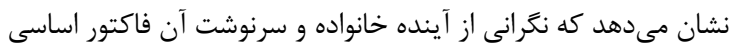




$$
\begin{aligned}
& \text { سوى يرستاران بخش، مرخص شدن برخى از بيماران بعد از شيمى }
\end{aligned}
$$

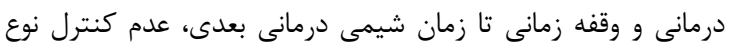

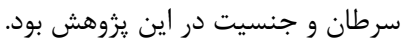

$$
\begin{aligned}
& \text { سياسگزارى }
\end{aligned}
$$

اين مقاله بركرفته از يايان نامه نويسندكان در مقطع كارشناسى ارشد

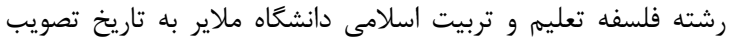

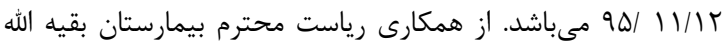

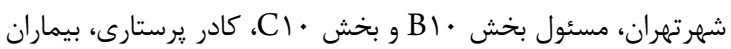

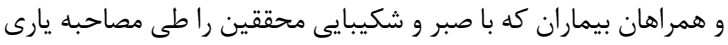

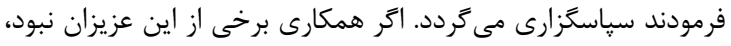
انجام يزوهش امكان يذير نمى خرديد. تضاد منافع

نويسندًان مقاله اعلام مىدارند كه در نَارش اين مقاله هيج كَنه تضاد

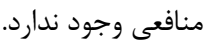

\section{References}

1. Anthony S. The child's discovery of death: a study in child psychology: Routledge; 2013

2. Yalom I. Existential psychology. Jackson, TN: Basic Books; 1980.

3. Kastenbaum R. Death, society, and human experience: Routledge; 2015

4. Boyle P, Levin B. World cancer report 2008. International Agency for Research on Cancer, 2008.

5. Gonen G, Kaymak SU, Cankurtaran ES, Karslioglu EH, Ozalp E, Soygur H. The factors contributing to death anxiety in cancer patients. J Psychosoc Oncol. 2012;30(3):347-58.

10.1080/07347332.2012.664260 pmid: 22571248

6. Sherman DW, Norman R, McSherry CB. A comparison of death anxiety and quality of life of patients with advanced cancer or AIDS and their family caregivers. J Assoc Nurses AIDS Care. 2010;21(2):99-112. doi: 10.1016/j.jana.2009.07.007 pmid: 20006525

7. Holzner B, Kemmler G, Cella D, De Paoli C, Meraner V, Kopp M, et al. Normative data for functional assessment of cancer therapy--general scale and its use for the interpretation of quality of life scores in cancer survivors. Acta Oncol. 2004;43(2):153-60. doi: 10.1080/02841860310023453 pmid: 15163163

8. Peters L, Cant R, Payne S, O'Connor M, McDermott F, Hood $\mathrm{K}$, et al. How death anxiety impacts nurses' caring for patients at the end of life: a review of literature. Open Nurs J. 2013;7:14-21. doi: 10.2174/1874434601307010014 pmid: 23400515

9. Imanzade A, Salahshori A. [An introduction to analaytic and meta-analytical approaches in philosophy of education]. Hamedan: Bu Ali Sina University Publisher; 2011.

10. Yalom I. Staring at the sun: Overcoming the dread of death: Scribe Publications; 2008.

11. Tillich P. Systematic theology. Chicago University of Chicago Press; 2011

12. Jaspers K. Philosophy. Chicago University of Chicago Press; 1996.

$$
\begin{aligned}
& \text { مىتواند تأثير بسزايى در روند بهبودى بيمارى داشته باشد. از يافتههاى }
\end{aligned}
$$

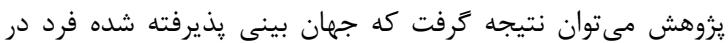

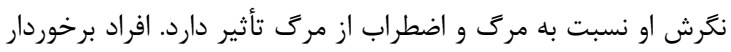

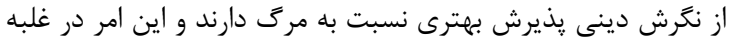

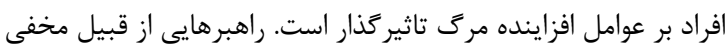

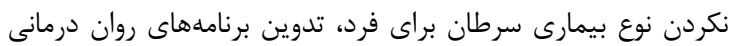

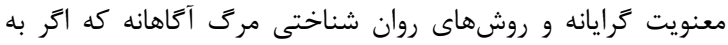

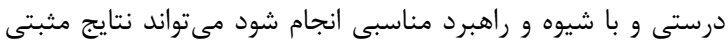

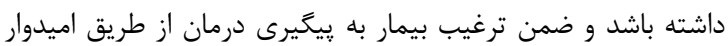

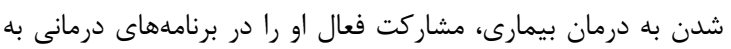

$$
\begin{aligned}
& \text { دنبال خواهد داشت. اين يزوهش عليرغم همكارى مسئولين مربوطه به به بهان }
\end{aligned}
$$

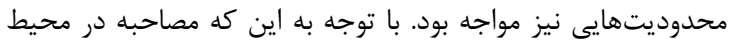

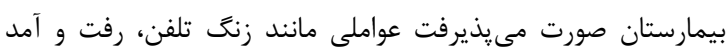

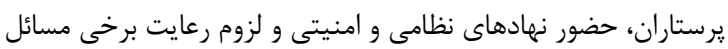

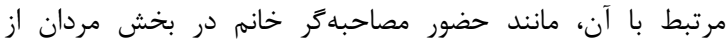

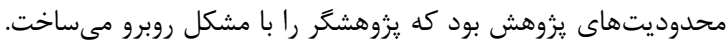

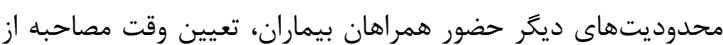

13. Jani S, Molaee M, JANGI GS, Pouresmali A. Effectiveness of cognitive therapy based on religious believes on death anxiety, social adjustment and subjective well-being in the cancer patients. J Ilam Univ Med Sci. 2014;22(94-103).

14. Salehi F, Mohsenzade F, Arefi M, Salehi Zahabi S, Amirifard N. Death Anxiety in Patients With Cancer in Kermanshah. Iran J Breast Dis. 2016;1(24-29).

15. Khezri L, Bahreyni M, Ravanipour M, Mirzaee K. The Relationship between spiritual wellbeing and depression or death anxiety in cancer patients in Bushehr 2015. Nurs Vulnerables. 2015;2(2):15-28.

16. Bahrami N, Moradi M, Soleimani M, Kalantari Z, Hosseini F. Death anxiety and its relationship with quality of life in women with cancer. Iran J Nurs 2013;26(82):5161.

17. Salajegheh S, Raghibi M. The effect of combined therapy of spiritual-cognitive group therapy on death anxiety in patients with cancer. J Shahid Sadoughi Univ Med Sci 2014;22(2):1130-9.

18. Lehto RH, Stein KF. Death anxiety: an analysis of an evolving concept. Res Theory Nurs Pract. 2009;23(1):2341. doi: $10.1891 / 1541-6577.23 .1 .23$ pmid: 19418886

19. Kesebir P. A quiet ego quiets death anxiety: humility as an existential anxiety buffer. J Pers Soc Psychol. 2014;106(4):610-23. doi: 10.1037/a0035814 pmid: 24660992

20. Jong J, Ross R, Philip T, Chang S-H, Simons N, Halberstadt J. The religious correlates of death anxiety: A systematic review and meta-analysis. Relig Brain Behav 2018;8(1):4-20.

21. Cerbone D. Understanding phenomenology: Routledge; 2014

22. Gerrish K, Lacey A. The research process in nursing: John Wiley \& Sons; 2010.

23. Adib Hajbagheri M, Parvizi S, Salsali M. [Qualitative research methods]. Tehran: Boshra Publication; 2004.

24. Bauer-Wu S, Farran CJ. Meaning in life and psychospiritual functioning: a comparison of breast cancer survivors and healthy women. J Holist Nurs. 
2005;23(2):172-90. doi: 10.1177/0898010105275927 pmid: 15883465

25. Imanzadeh A. Nurses' Lived Experiences of Forgiveness to Others. J Qual Res Health Sci. 2017;5(337-348).

26. Meleis AI, Jonsen AR. Ethical crises and cultural differences. West J Med. 1983;138(6):889-93. pmid: 6613119

27. Herth K. Enhancing hope in people with a first recurrence of cancer. J Adv Nurs. 2000;32(6):1431-41. pmid: 11136411

28. Benzein EG, Berg AC. The level of and relation between hope, hopelessness and fatigue in patients and family members in palliative care. Palliat Med. 2005;19(3):23440. doi: 10.1191/0269216305pm1003oa pmid: 15920938

29. Rowland J. Breast cancer: Psychosocial aspects. Behavioral medicine and women: A comprehensive handbook: Guilford Press; 1998. p. 577-87.

30. Ho MY, Cheung FM, Cheung SF. The role of meaning in life and optimism in promoting well-being. Pers Individ Differ 2010;48(5):658-63. doi: 10.1016/j.paid.2010.01.008

31. Feldman DB, Snyder CR. Hope and the Meaningful Life: Theoretical and Empirical Associations Between GoalDirected Thinking and Life Meaning. J Soc Clin Psychol. 2005;24(3):401-21. doi: 10.1521/jscp.24.3.401.65616

32. Lifton R. Death in life: Survivors of Hiroshima. Carolina University of North Carolina Press; 2012.

33. Roy-Byrne PP, Davidson KW, Kessler RC, Asmundson GJ, Goodwin RD, Kubzansky L, et al. Anxiety disorders and comorbid medical illness. Gen Hosp Psychiatry. 2008;30(3):208-25.

doi: 10.1016/j.genhosppsych.2007.12.006 pmid: 18433653

34. Mennin DS, Heimberg RG, Turk CL, Fresco DM. Applying an Emotion Regulation Framework to
Integrative Approaches to Generalized Anxiety Disorder. Clin Psychol Sci Pract 2006;9(1):85-90. doi: 10.1093/clipsy.9.1.85

35. Werner KH, Goldin PR, Ball TM, Heimberg RG, Gross JJ. Assessing Emotion Regulation in Social Anxiety Disorder: The Emotion Regulation Interview. J Psychopathol Behav Asses 2011;33(3):346-54. doi: 10.1007/s10862-0119225-x

36. Bastani F, Sayahi S, Haghani H. Social support and relationship with hope among mothers of a child with leukemia. J Clin Nurs Midwifery. 2012;1.

37. Muramatsu N, Yin H, Hedeker D. Functional declines, social support, and mental health in the elderly: does living in a state supportive of home and community-based services make a difference? Soc Sci Med. 2010;70(7):1050-8. 10.1016/j.socscimed.2009.12.005 pmid: 20117865

38. Zielinski MJ, Veilleux JC. Examining the relation between borderline personality features and social support: The mediating role of rejection sensitivity. Pers Individ Differ. 2014;70:235-8. doi: 10.1016/j.paid.2014.07.005

39. Distefano M, Riccardi S, Capelli G, Costantini B, Petrillo M, Ricci C, et al. Quality of life and psychological distress in locally advanced cervical cancer patients administered pre-operative chemoradiotherapy. Gynecol Oncol. 2008;111(1):144-50. doi: 10.1016/j.ygyno.2008.06.034 pmid: 18692225

40. Watson M, Homewood J, Haviland J. Coping response and survival in breast cancer patients: a new analysis. Stress Health. 2012;28(5):376-80. doi: 10.1002/smi.2459 pmid: 23129557

41. Sadjadian A, Haghghat S, Montazeri A, Kazemnedjad A, Alavinili A. Post diagnosis coping strategies patients with breast cancer. Iran J Breast Dis 2011;4(3):52-8. 